c.3

US Army Corps of Engineers

Waterways Experiment

Station

\title{
An Evaluation of Solidification/Stabilization for Treatment of New York/New Jersey Harbor Sediments
}

by Michael G. Channell, Daniel E. Averett 
The contents of this report are not to be used for advertising, publication, or promotional purposes. Citation of trade names does not constitute an official endorsement or approval of the use of such commercial products.

The findings of this report are not to be construed as an official Department of the Army position, unless so designated by other authorized documents.

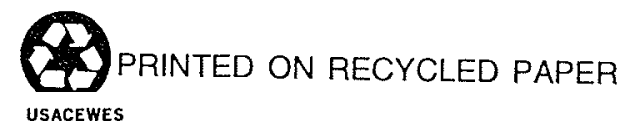




\section{An Evaluation of Solidification/Stabilization for Treatment of New York/New Jersey Harbor Sediments}

by Michael G. Channell, Daniel E. Averett

U.S. Army Corps of Engineers

Waterways Experiment Station

3909 Halls Ferry Road

Vicksburg, MS 39180-6199

Final report

Approved for public release; distribution is unlimited 


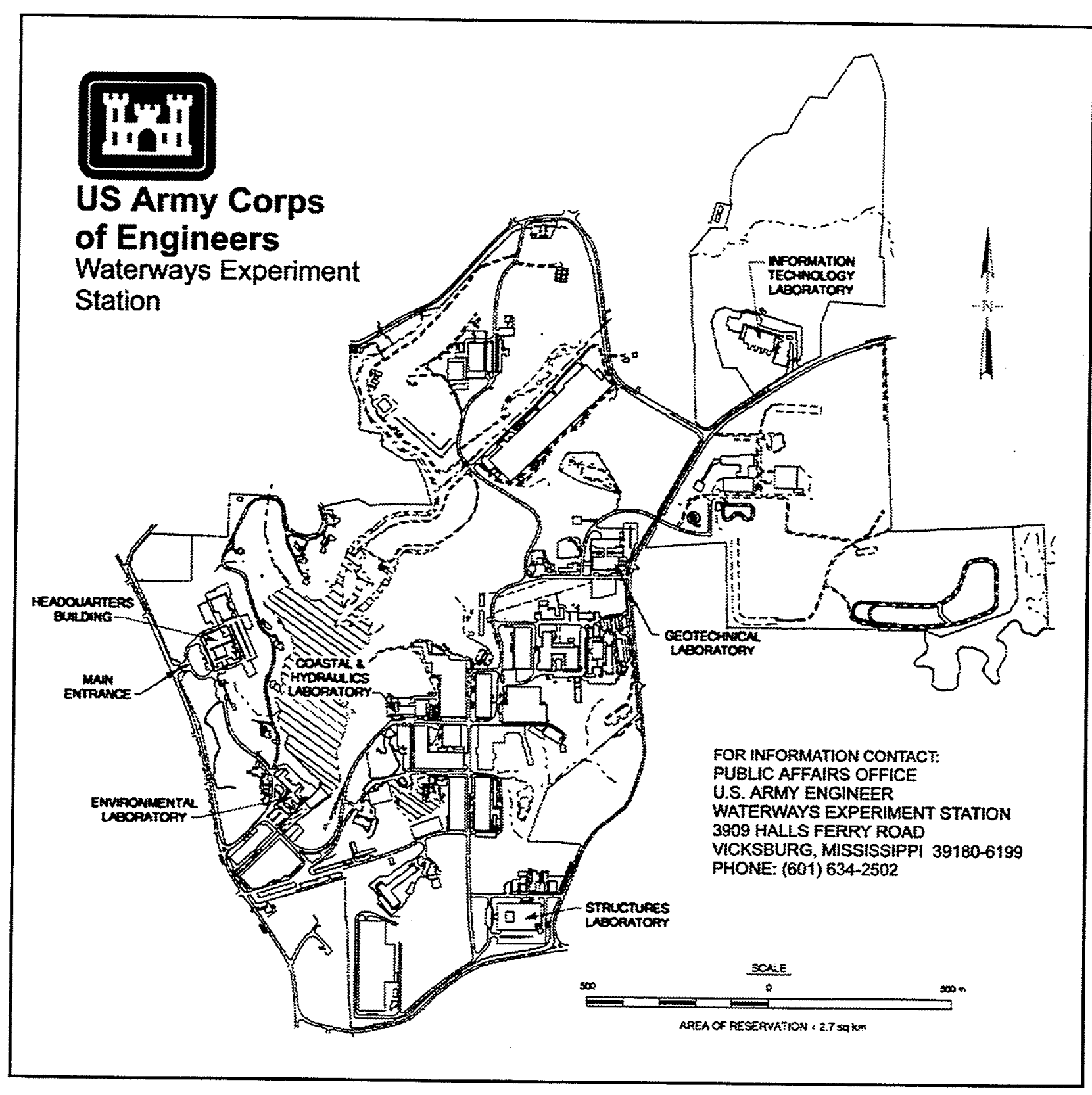

\section{Waterways Experiment Station Cataloging-in-Publication Data}

Channell, Michael G.

An evaluation of solidification/stabilization for treatment of New York/New Jersey Harbor sediments / by Michael G. Channell, Daniel E. Averett ; prepared for U.S. Army Engineer District, New York.

62 p. : ill. ; $28 \mathrm{~cm}$. - (Technical report ; EL-97-10)

Includes bibliographic references.

1. Dredging spoil - New York (State) 2. Spoil banks - New York (State) 3. Harbors New York (State) 4. Harbors - New Jersey. I. Averett, Daniel E. II. United States. Army. Corps of Engineers. New York District. III. U.S. Army Engineer Waterways Experiment Station. IV. Environmental Laboratory (U.S. Army Engineer Waterways Experiment Station) V. Title. VI. Series: Technical report (U.S. Army Engineer Waterways Experiment Station) ; EL-97-10.

TA7 W34 no.EL-97-10 


\section{Contents}

Preface $\ldots \ldots \ldots \ldots \ldots \ldots \ldots \ldots \ldots \ldots \ldots \ldots \ldots$

Conversion Factors, Non-SI to SI Units of Measurement $\ldots \ldots \ldots \ldots \ldots$ vi

1 -Introduction $\ldots \ldots \ldots \ldots \ldots \ldots \ldots \ldots \ldots \ldots \ldots \ldots \ldots$

Background $\ldots \ldots \ldots \ldots \ldots \ldots \ldots \ldots \ldots \ldots \ldots \ldots \ldots \ldots \ldots \ldots$

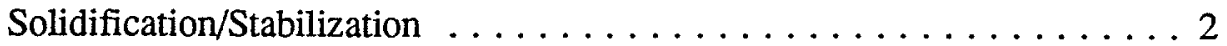

Objective and Scope ..................... 4

Organization of the Report $\ldots \ldots \ldots \ldots \ldots \ldots \ldots \ldots \ldots$

$2-\mathrm{S} / \mathrm{S}$ Material and Methods $\ldots \ldots \ldots \ldots \ldots \ldots$

Approach . . . . . . . . . . . . . . . . . . . . 5

Sample Collection . . . . . . . . . . . . . . . . . . . 5

Untreated Sediment Characterization . . . . . . . . . . . 6

Preparation of the Test Specimens . . . . . . . . . . . . . 8

Detailed Evaluation Testing $\ldots \ldots \ldots \ldots \ldots \ldots \ldots$

3-Discussion of Results . . . . . . . . . . . . . . 13

Characterization Results for Untreated Sediment . . . . . . . . . . 13

Initial Screening Test . . . . . . . . . . . . . . . . . . 16

Detailed Evaluation Results $\ldots \ldots \ldots \ldots \ldots \ldots$

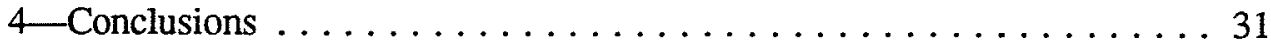

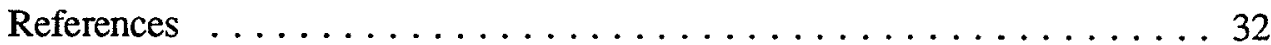

Appendix A: Physical/Chemical Tests Performed on Untreated

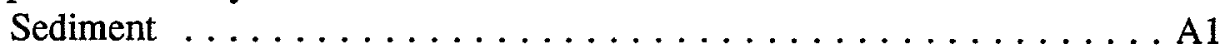

Appendix B: Initial Screen Test Results $\ldots \ldots \ldots \ldots \ldots \ldots$. . . .

Appendix C: Results of Detailed Evaluation $\ldots \ldots \ldots \ldots \ldots \ldots$ C1

SF 298 


\section{List of Figures}

Figure 1. Schematic flowchart for stabilization processing $\ldots \ldots \ldots .8$

Figure 2. CI results for IST cement binder . . . . . . . . . . . 19

Figure 3. CI results for IST lime/fly ash binder . . . . . . . . . . . 19

Figure 4. Percent volume increase of cement BSR samples . . . . . . 22

Figure 5. Percent volume increase of lime/fly ash BSR samples . . . . 22

Figure 6. CI test for cement BSR samples ............. 23

Figure 7. CI test for lime/fly ash BSR samples . . . . . . . . . 24

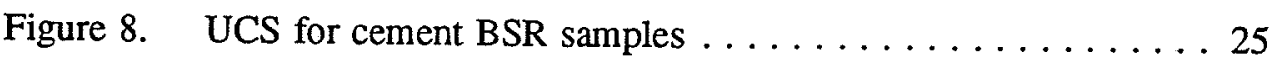

Figure 9. UCS for lime/fly ash BSR samples ............ 25

Figure 10. Comparison of UCS for untreated sediment and cement

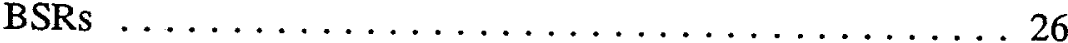

Figure 11. Comparison of UCS for untreated sediment and lime/fly ash BSRs .................... 27

\section{List of Tables}

Table 1. Matrix of Specimens Prepared for Initial Sediment/Binder Screening $\ldots \ldots \ldots \ldots \ldots \ldots \ldots \ldots \ldots \ldots \ldots \ldots \ldots \ldots$

Table 2. Average Results of Physical Tests Conducted on Untreated Sediment . . . . . . . . . . . . . . . . 13

Table 3. Average Bulk Chemical Analysis of Untreated Sediment

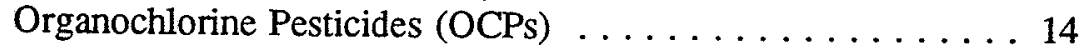

Table 4. Average Bulk Chemical Analysis of Untreated Sediment, PAHs ..................... 15

Table 5. Average Bulk Chemical Analysis of Untreated Sediment,

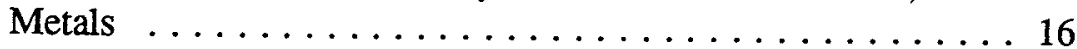

Table 6. Average Bulk Chemical Analysis of Untreated Sediment, PCBs ........................ 17

Table 7. Average Bulk Chemical Analysis of Untreated Sediment Dioxins and Furans $\ldots \ldots \ldots \ldots \ldots \ldots$

Table 8. Average IST $48-\mathrm{Hr}$ CI Data .............. 20

Table 9. Average Results of Metals for the TCLP for the Detailed

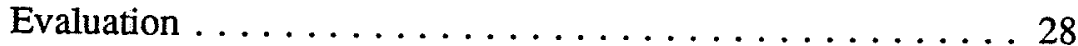

Table 10. Normalized Results of TCLP . . . . . . . . . . . 29 


\section{Preface}

The work reported herein was conducted by the U.S. Army Engineer Waterways Experiment Station (WES) for the U.S. Army Engineer District, New York. The report was prepared by Mr. Michael G. Channell and Mr. Daniel E. Averett of the Environmental Restoration Branch (ERB), Environmental Engineering Division (EED), Environmental Laboratory (EL), WES.

The work was conducted under the general supervision of Mr. Norman R. Francingues, Chief, EED, and Dr. John Harrison, Director, EL. Project officer for the U.S. Army Engineer District, New York, was Mr. Kerwin Donato.

At the time of publication of this report, Dr. Robert W. Whalin was Director of WES. COL Bruce K. Howard, EN, was Commander.

This report should be cited as follows:

Channell, M. G., and Averett, D. E. (1997). "An evaluation of solidification/stabilization for treatment of New York/New Jersey Harbor sediments," Technical Report EL-97-10, U.S. Army Engineer Waterways Experiment Station, Vicksburg, MS. 


\section{Conversion Factors, Non-SI to SI Units of Measurement}

Non-SI units of measurement used in this report can be converted to SI units as follows:

\begin{tabular}{|l|l|l|}
\hline Multiply & By & To Obtain \\
\hline \hline cubic yards & 0.7645549 & cubic meters \\
\hline degrees (angle) & 0.01745329 & radians \\
\hline foot-pounds (force) & 1.355818 & meter-newtons or joules \\
\hline gallons (U.S. liquid) & 3.785412 & liters \\
\hline inches & 2.54 & centimeters \\
\hline pounds (mass) & 0.4535924 & kilograms \\
\hline square inches & 6.4516 & square centimeters \\
\hline
\end{tabular}




\section{Introduction}

\section{Background}

Sediments from the New York/New Jersey Harbor must be routinely dredged to maintain navigable water depths for shipping channels and berthing areas for commerce and safe navigation. Ocean disposal has historically been used as the primary alternative for disposal of dredged materials. However, the sediments that accumulate in the Harbor may contain contaminants at concentrations high enough to prohibit direct ocean disposal or beneficial use.

Dredged sediments must pass testing criteria prior to unrestricted ocean disposal. The recently revised regional guidance, Guidance for Performing Tests on Dredged Material Proposed for Ocean Disposal (Draft December 1992), has established more stringent biological and chemical test criteria. As a result, the volume of contaminated dredged material prohibited from unrestricted ocean disposal has increased dramatically.

The U.S. Environmental Protection Agency, Region II (USEPA) and the U.S. Army Engineer District, New York, are actively seeking and investigating sediment decontamination technologies for dredged material management. Section 405 of the Water Resources and Development Act of 1992 authorized an investigation, including testing and demonstration, of decontamination technologies and their potential application to contaminated sediments to maintain harbor navigation in an environmentally acceptable, cost-effective manner. Decontamination and management of contaminated sediments involve the integration of a number of steps (e.g., dredging, transportation, pretreatment, treatment, posttreatment, and disposal or reuse) into a system that can be used on a routine basis. Although the exact amount of material requiring treatment in the future has yet to be determined, an estimate of approximately $500,000 \mathrm{cu} \mathrm{yd}^{1}$ per year is the target figure for projecting full-scale facility operations.

The Section 405 Program includes the investigation of proprietary and nonproprietary technologies. The proprietary technology investigation is being

\footnotetext{
1 A table of factors for converting non-SI units of measurement to SI units is presented on page vi.
} 
administered by the Brookhaven Rensselaer Environmental Partnership. Seven vendors were selected to perform bench-scale tests; four of these vendors were selected to proceed to pilot-scale testing based on results of the bench-scale tests and economic analyses. The nonproprietary bench-scale testing was performed by the U.S. Army Engineer Waterways Experiment Station (WES). These tests parallel the proprietary testing and offer an opportunity for larger scale testing using technologies that can be procured at full scale on the open market. The nonproprietary tests selected for investigation by WES are portland cement solidification/stabilization (S/S), lime and flyash $S / S$, and manufactured soil for beneficial use. As a separate work assignment, laboratory tests were conducted to investigate pretreatment technologies necessary as part of the process train. These tests include an evaluation of dewatering techniques, such as filtration and natural consolidation/desiccation, and an assessment of the quality and treatment requirements for water separated from the dredged material prior to treatment.

\section{Solidification/Stabilization}

Effects of contaminated sediment on water quality can be reduced by a number of control or treatment technologies. Alternatives for reducing or eliminating contaminant transport from the ocean-disposed sediment into the water column include isolating the contaminated sediment from the water by capping with a layer of clean sediment or treating the sediment prior to ocean disposal. Other remediation options involve removing the contaminated material from the waterway and treating or disposing of the dredged material so that contaminants are removed, destroyed, immobilized, or efficiently contained within a disposal site. However, treatment options that efficiently extract or destroy contaminants are expensive, and unrestricted dredged material disposal in a confined disposal facility provides the potential for leaching of contaminants into groundwater or surface water for highly contaminated sediments.

$\mathrm{S} / \mathrm{S}$ is a promising treatment technology for containing and immobilizing dredged material contaminants within a disposal site. S/S technology has been applied in Japan to bottom sediments containing toxic substances (Otsuki and Shima 1982; Kita and Kubo 1983) and in the United States to industrial wastes (Cullinane, Jones, and Malone 1986). Laboratory investigation of S/S of dredged material has been performed at Indiana Harbor, Indiana (Environmental Laboratory 1987); Everett Bay, Washington (Palermo et al. 1989); New Bedford Harbor, Massachusetts (Myers and Zappi 1989); and Buffalo River, New York (Fleming et al. 1991). While S/S is not a solution to every disposal problem, the technology offers improved physical characteristics that reduce the accessibility of water to contaminated solids and reduced leachability for many contaminants.

Myers and Zappi (1989) have described S/S for dredged material. Solidification is the process of eliminating the free water in a semisolid by hydration 
with a setting agent(s) or binder(s). Stabilization can be both physical and chemical. Solidification usually provides physical stabilization but not necessarily chemical stabilization.

Physical stabilization refers to improved engineering properties such as bearing capacity, trafficability, and permeability. Alteration of the physical character of the material to form a solid material reduces the accessibility of water to the contaminants within a cemented matrix and entraps or microencapsulates the contaminated solids within a dimensionally stable matrix. Since most of the contaminants in dredged material are tightly bound to the particulate fraction, physical stabilization is an important contaminant immobilization mechanism (Myers and Zappi 1989).

Chemical stabilization is the alteration of the chemical form of the contaminants to make them resistant to aqueous leaching. S/S processes are formulated to minimize the solubility of metals by controlling $\mathrm{pH}$ and alkalinity. Anions, which are more difficult to bind in insoluble compounds, may be immobilized by entrapment or microencapsulation. Chemical stabilization of organic compounds may be possible, but the mechanisms involved are poorly understood (Myers and Zappi 1989).

Binders include cements, pozzolans, or thermoplastics (Cullinane, Jones, and Malone 1986). In certain instances, proprietary additives may also be added to the process. Results of reaction of binders to the contaminated sediment are not always predictable due to varying contaminant types and contaminant concentrations within the test material. Therefore, laboratory leach tests must be conducted on a sediment-specific basis. Discussions of S/S processes are provided in Malone and Jones (1979); Malone, Jones, and Larson (1980); and U.S. Environmental Protection Agency (USEPA) (1986a).

Binders selected for potential application to New York/New Jersey Harbor sediments are as follows:

a. Portland cement.

b. Lime/fly ash.

These binders were selected because of their nonproprietary nature and ready availability. They have been used in a number of S/S studies at WES, including assessment of Best Demonstrated Available Technology for a number of listed hazardous wastes. Portland cement addition results in the formation of a concrete-like monolith. Lime/fly ash pozzolanic processes combine the properties of lime and fly ash to produce low-strength cementation. 


\section{Objective and Scope}

The objectives of this study were as follows:

a. Determine if $\mathrm{S} / \mathrm{S}$ techniques can be applied to contaminated sediments to reduce contaminant leaching and render dredged material acceptable for ocean disposal, upland disposal, or beneficial use.

b. Evaluate the physical properties of the solidified/stabilized sediments to determine if $S / S$ techniques will substantially improve the physical handling properties of the sediment.

c. Determine the $\mathrm{S} / \mathrm{S}$ process and formulation to be used in planning for pilot-scale demonstration of $S / S$ treatment and disposal.

The scope of the study involved laboratory preparation of S/S samples using New York/New Jersey Harbor sediment and the following binders: portland cement and lime/fly ash. A range of binder-to-weight wet sediment ratios (BSRs) were screened, and an optimum ratio was selected for detailed evaluation for each binder process. Effectiveness was measured by comparing leaching results and unconfined compressive strength (UCS).

\section{Organization of the Report}

This report is divided into four chapters:

a. Chapter 1 provides the background information around which this study evolved.

b. Chapter 2 describes the materials and methods used to evaluate $\mathrm{S} / \mathrm{S}$ of the New York/New Jersey Harbor sediment.

c. Chapter 3 discusses the results of the physical and chemical tests run on the $\mathrm{S} / \mathrm{S}$ sediment.

d. Chapter 4 presents conclusions regarding S/S of New York/New Jersey Harbor sediment. 


\section{S/S Materials and Methods}

\section{Approach}

This study was conducted in five phases:

a. Phase I: Sample collection. Sample collection was performed by the U.S. Army Engineer District, New York. Samples were composited and shipped to WES by the Brookhaven National Laboratory, Upton, New York.

b. Phase II: Screening tests. Initial screening tests were performed to narrow the range of binder dosages and water-to-sediment ratios for preparing the test specimens. Moisture contents were evaluated to determine whether addition of water was necessary and to evaluate the success of homogenization efforts.

c. Phase III: Preparation of test specimens for detailed evaluation. The sediment was mixed with binders and cured under controlled conditions.

d. Phase IV: Physical and chemical testing. Based on results of the UCS and toxicity characteristic leaching procedure (TCLP) leachability of metals, specimens were selected for detailed evaluation of contaminant leachability.

e. Report Preparation. Results from the physical and chemical tests were used to develop conclusions regarding S/S of New York/New Jersey Harbor sediment.

\section{Sample Collection}

The material of interest was contaminated sediment collected from the Newtown Creek Site in the New York/New Jersey Harbor. Sediment samples were collected and placed into a 250-gal tank for homogenization. The sample was homogenized in the field using a Lightnin model XJ-350 portable impeller agitator. Once the sample was homogenized, subsamples were taken for WES 
and the seven BNL vendors. The WES sample was packaged in four 30-gal plastic drums and shipped to WES. Upon receiving the samples, the sediment was stored at $4{ }^{\circ} \mathrm{C}$ for testing.

\section{Untreated Sediment Characterization}

Physical characteristics of the untreated sediment were evaluated using the following test procedures. Test specimens were prepared in accordance with the requirements of the test method discussed below.

\section{Moisture content}

The moisture content for the sediment was determined according to modified ASTM D-2216 (American Society of Testing and Materials (ASTM) 1992a). This method was modified by drying the sample to constant weight at $60{ }^{\circ} \mathrm{C}$. Lower temperatures are used with contaminated materials to avoid removing large volumes of the contaminants and to reduce the release of hydrated water from the sample. The moisture contents were used to calculate the dry weight of each sample. The moisture content was also used as an expedient method to evaluate the degree of homogeneity of the sediment samples.

\section{Bulk density}

The bulk density of the sediment was measured according to ASA 13 (American Society of Agronomy (ASA) 1965). This test was performed on the untreated sample by loosely placing a known mass of sediment into a mold of known volume. This density represents the uncompacted laboratory density of the sediment as it was used in the S/S treatability study. The laboratory bulk density is not the in situ density, which is measured in the field. Laboratory density loosely approximates the field density of uncompacted excavated sediment. The bulk densities were calculated using the mass and volume data and were reported in units of pounds per cubic foot.

\section{Grain-size analysis}

The grain-size distribution for the sediment was determined according to EM 1110-2-196 Appendix VII (U.S. Army Corps of Engineers 1970). This method uses a combination of sieving and a hydrometer for analysis. 


\section{Atterberg limits}

The Atterberg limits for the sediment were determined according to ASTM D-4318 (ASTM 1992a). This test is used to determine the water content at the boundaries between the plastic and liquid states of the sediment. The plastic limit is the water content at which the sediment will start to crumble when rolled into a 3-mm thread under the palm of the hand. The liquid limit is defined as the lowest water content at which the sediment will flow as a viscous liquid.

\section{Proctor density}

The proctor density for the sediment was determined according to ASTM D-698 (ASTM 1992b). This procedure defines the relationship between water content and the dry unit weight of the solids compacted with an effort of $12,400 \mathrm{ft}-\mathrm{lb} / \mathrm{ft}^{3}$. Optimal proctor density is the maximum density (reported as pounds/cubic foot) that can be achieved at $12,400 \mathrm{ft}-1 \mathrm{~b} / \mathrm{ft}^{3}$. The sediment moisture content at which the maximum proctor density occurs was also measured.

\section{Unconfined compressive strength}

The unconfined compressive strength was determined for the sediment. The UCS measurements were conducted according to modified ASTM C-109 (ASTM 1992a). The main deviation from this method was that the untreated samples were prepared by adding water to the sediments at 85 percent of optimal moisture required for maximum compaction and compacting the sediments in the 2-in. cube molds using the compaction effort as described in the Proctor density section. A special compaction hammer with a 1.8 - by 1.0 -in. rectangular head and a drop weight of $2.49 \mathrm{~kg}$ was used to deliver the compactive effort. The samples were aged for 7 days in an environment controlled at $23{ }^{\circ} \mathrm{C} \pm 2^{\circ}$ and 95 -percent \pm 5 -percent relative humidity prior to testing. After removal from the mold, the surface area of each sample was determined using a Fowler Max-Cal Caliper. The cubes were placed in plastic bags, and each cube was subjected to a compressive force until the cube fractured. A Tinius Olsen Super-L compressive apparatus was used to supply this force and indicate the compressive strength at which the cubes fractured. The UCS of each cube was reported as the force required to fracture the cube in pounds per square inch (psi) of surface area.

\section{Resistance to penetration}

The Cone Index (CI) determination was performed for the sediment and was conducted according to TM 5-540 (Headquarters, Department of the Army 1971). The CI measures the resistance of a material to the penetration of a 30-deg right circular cone. The $\mathrm{CI}$ value is reported as force per unit surface 
area (psi) of the cone base required to push the cone through a test material at a rate of 72 in./min. Two cones are available for this test: (a) the standard WES cone having an area of $0.5 \mathrm{sq}$ in. and (2) the airfield penetrometer having a base area of $0.2 \mathrm{sq}$ in. Because of its smaller cone, the airfield penetrometer can measure larger CI values. It was convenient to use the standard WES cone penetrometer on materials with a CI up to 300 psi. The maximum $\mathrm{CI}$ value that can be measured by the airfield penetrometer is 750 psi; therefore, materials having CI values greater than $750 \mathrm{psi}$ are reported simply as $>750$ psi.

\section{Specific gravity}

The specific gravity (SG) for the sediment was determined according to ASTM D-854 (ASTM 1992b). SG is the ratio of the mass of a unit volume of the sediment at a stated temperature to the mass in air of the same volume of gas-free distilled water at a stated temperature. SG is typically utilized as an indication of the soil particle density. SG measurements are unit-less but are generally referenced to the density of water.

\section{Preparation of the Test Specimens}

Two processes were used to solidify/stabilize the sediment from the Newtown Creek Site of the New York/New Jersey Harbor. The two processes used for this study were portland cement and lime with class F fly ash. The $S / S$ process involves the addition of water and binder material to the sediment followed by a mixing and a curing period. A flowchart of $S / S$ processing is shown as Figure 1.

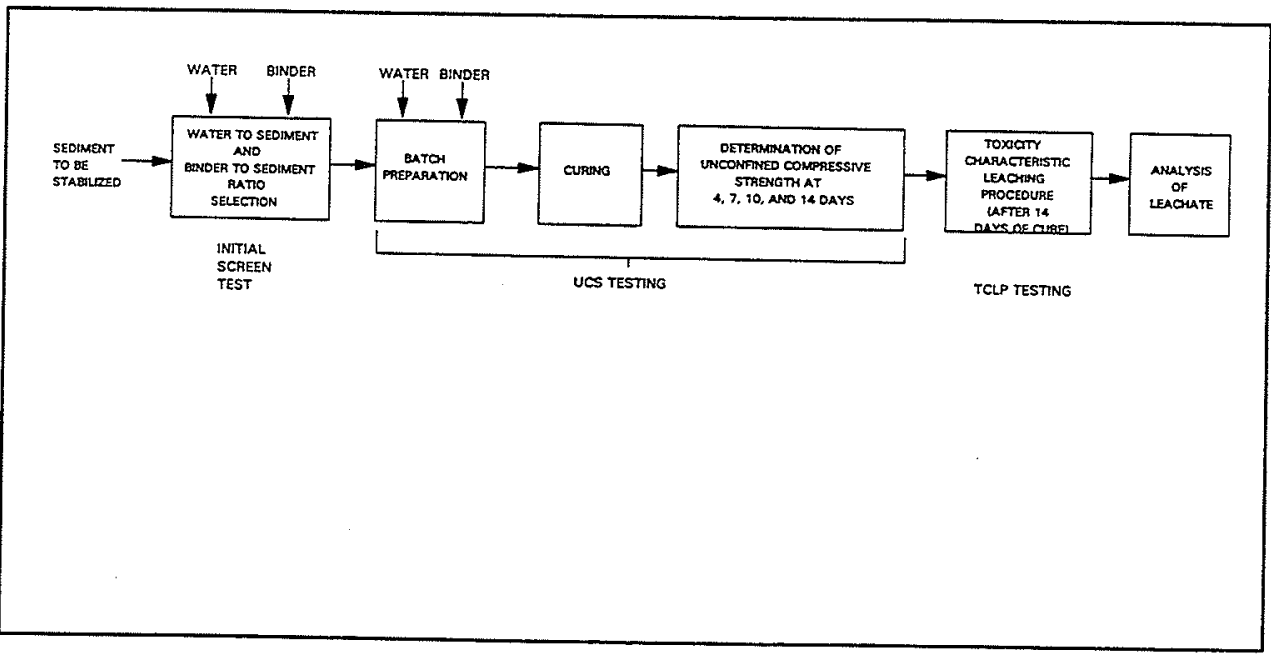

Figure 1. Schematic flowchart for stabilization processing 
WES prepared generic chemical S/S formulations for two binder systems (cement and lime/fly ash). An initial screening test (IST) was used to narrow the range of binder to sediment ratios (BSRs) and water to sediment ratios (WSRs) necessary for detailed S/S treatment of the sediment. The sediment did not require the addition of water to the sample for hydration of the binder. The IST involved mixing binder and sediment in a K455S Hobart mixer at two WSRs. The two WSRs were the sediment as received at approximately 70-percent moisture and the sediment air-dried to 58-percent moisture. These ratios were chosen on a basis of previous experience of the testing personnel and the moisture content of each of the sediments. Two binders, three BSRs, and two WSRs, for a total of 12 evaluations, were evaluated for the sediment in the IST phase of the study as shown in Table 1.

\begin{tabular}{||l|l|l||}
\hline \multirow{2}{*}{$\begin{array}{l}\text { Table 1 } \\
\text { Matrix of Specimens Prepared for Initial Sediment/Binder } \\
\text { Screening }\end{array}$} & \multicolumn{1}{|c||}{ Indicated Water/Sediment Ratio } \\
\cline { 2 - 4 } & 70-Percent Moisture & 58-Percent Moisture \\
\hline \hline & \multicolumn{1}{|c|}{ Binder: Cement } \\
\hline \hline $\begin{array}{l}\text { Cement } \\
0.2\end{array}$ & 1 & 1 \\
\hline 0.4 & 1 & 1 \\
\hline 0.7 & 1 & 1 \\
\hline \hline & \multicolumn{1}{|c|}{ Binder: Lime/Fly Ash } \\
\hline \hline $\begin{array}{l}\text { Lime/Fly Ash } \\
0.2 / 0.2\end{array}$ & 1 & 1 \\
\hline $0.3 / 0.3$ & 1 & 1 \\
\hline $0.4 / 0.4$ & 1 & 1 \\
\hline
\end{tabular}

After each formulation was mixed for $10 \mathrm{~min}$, the mixture was placed in 4-in.-diam by 4-in.-high-cylindrical molds. These mixtures were either poured into the molds and vibrated on a Syntron model VP61D1 vibration table or compacted in the molds using the standard proctor effort as described previously under the Proctor density section. The samples were placed in a controlled environment at $23{ }^{\circ} \mathrm{C} \pm 2{ }^{\circ} \mathrm{C}$ and 95 -percent relative humidity \pm 5 percent until needed for testing.

Determination of the optimal WSRs and BSRs was based on the results of the CI test performed on the IST samples during a 48-hr curing period. CI measurement, as described in sediment characterization, was performed on these samples at $2,4,8,24$, and $48 \mathrm{hr}$ of cure. 


\section{Detailed Evaluation Testing}

\section{Sample preparation}

Four formulations of cement and four formulations of lime/fly ash were prepared in duplicate for the sediment during the detailed $S / S$ evaluations. Solidified/stabilized specimens were prepared by mixing water and binders with the contaminated sediment in a Hobart C-600 mixer. The sediment and additives were mixed for $5 \mathrm{~min}$; the sides of the container were scraped to remove adhering material; and the mixture was mixed an additional $5 \mathrm{~min}$. When mixing was complete, the sample was subjected to the paint filter test (USEPA 1986b) to determine if free liquid was present in the mixture.

Mixtures that were determined not to have free water were poured into molds. A variety of specimens were prepared based upon the various test protocols. To aid in removing test specimens from the molds, a light coating of grease was applied to the molds used to cast the UCS specimens. Specimens used for the TCLP were placed in ungreased molds to avoid possible chemical contamination from the grease. Immediately after the additive/ sediment mixtures were placed in the molds, they were vibrated on a Sentron model VP61D1 vibration table to remove voids. Some of the mixtures were viscous so that vibration was an ineffective method for removing voids. These specimens were tamped according to ASTM C 109-86 (ASTM 1990) using a model CT-25A tamper.

The molded solidified/stabilized materials were cured in the molds at $23{ }^{\circ} \mathrm{C}$ and 98-percent relative humidity for a minimum of $24 \mathrm{hr}$. Specimens were removed from the molds when they developed sufficient strength to be free standing and were cured under the same temperature and relative humidity conditions until required for further testing. After the solidified/stabilized sediment had cured for 28 days, the physical and chemical properties of the S/S sediment were determined.

\section{Evaluation methods}

The success of an S/S process can be evaluated in a number of ways. For this study, eight physical tests and one chemical test were used. The following sections describe the method protocol for physical and chemical testing used for the detailed evaluation phase of this study.

Unconfined compressive strength. The unconfined compressive strength of the solidified/stabilized sediment samples was determined using the method specified previously in the Untreated Sediment Characterization section of this report. UCS testing was performed on the S/S cubes after they had cured for $7,14,21$, and 28 days. Three cubes for each binder and each formulation were tested at these curing periods. A total of 96 cubes were prepared and evaluated for UCS. 
Set time. The set time is defined as the time required to develop sufficient rigidity following mixing to resist the penetration of a standard rod or needle. Set times for the S/S samples were evaluated using the $\mathrm{CI}$ as described in the Untreated Sediment Characterization section of this report. Measurements were taken on samples after they had cured $2,4,8,24$, and $48 \mathrm{hr}$. CI tests were performed in triplicate for each binder, each formulation, and each replicate $(\mathrm{A}, \mathrm{B}$, and $\mathrm{C})$.

Slump test. Workability of the treated specimens was evaluated using the slump test, ASTM method C 143 (ASTM 1987). Slump was determined by measuring the vertical displacement of the center of the treated sample after $2.5 \mathrm{~min}$. Slump measurements were performed for each binder formulation for the sediment.

Bulk density. Three bulk density determinations for the S/S samples were performed for each binder and each formulation. A total of 24 cubes were tested for the sediment for bulk density after they had cured for 28 days under a controlled environment. Density determinations were performed according to the procedures previously described under the Untreated Sediment Characterization section of this report. Estimates of the percentage volume increases resulting from $S / S$ were determined by comparing the volume of a known unit weight of contaminated sediment before and after $S / S$. Equations 1 through 3 were used in calculating the percent volumetric change for the solidified/ stabilized sediment.

For the untreated sediment,

$$
V_{1}=\frac{W_{s}}{D_{1}}
$$

where

$V_{1}=$ volume of sediment

$W_{s}=$ weight of sediment

$D_{1}=$ proctor density of untreated sediment

For the solidified/stabilized sediment,

$$
V_{2}=\frac{\left(W_{s}+\left(R \times W_{s}\right)\right)}{D_{2}}
$$


where

$$
\begin{gathered}
V_{2}=\text { volume of binder to sediment } \\
R=\text { binder-to-sediment ratio (BSR) } \\
D_{2}=\text { bulk density of sediment and binder } \\
\% \text { Volumetric Change }=\frac{\left(V_{2}-V_{1}\right)}{V_{1}}
\end{gathered}
$$

Bleed water. Bleed water is defined as the relative quantity of mixing water that will bleed from a freshly mixed concrete. The amount of bleed water produced in each formulation selected for detailed evaluation was measured using ASTM Method C 232 (Bleeding of Concrete, ASTM 1987). To determine if the mixtures produced bleed water, samples were visually inspected to determine if a water layer was present. ASTM method C-232 method $\mathrm{A}$ was used to measure the quantity of this bleed water.

Cracking. There are no known standard test procedures for measuring the degree of cracking. The sample specimens were visually inspected for cracks. Development of cracks is considered to be detrimental to solidified samples. The formation of cracks increases the surface area of the sample. One of the purposes of the $S / S$ process is to decrease the surface area of the waste by the formation of a monolith. The formation of cracks increases the potential for water infiltration by increasing the waste's surface area, thus increasing the potential for contaminant leaching.

Moisture content. Three moisture content determinations for the solidified/stabilized samples were performed for each sediment, each binder, each formulation, and each replicate (A and B). A total of 48 samples for each sediment were crushed to pass a $9.5-\mathrm{mm}$ sieve and tested for moisture content after they had cured for 28 days under a controlled environment. Moisture content determinations were performed following the procedures previously described under the Untreated Sediment Characterization section of this report.

Specific gravity. Specific gravity was evaluated for each replicate (A, B, and $C$ ) for each formulation for each binder system for the sediment. The method followed is outlined in the Untreated Sediment Characterization section of this report.

Toxicity characteristic leaching procedure. TCLP extractions were performed on the solidified/stabilized samples after 28 days of curing for each binder, each formulation, and each replicate. The TCLP extracts were analyzed for the contaminants of concern for each sediment. The TCLP was performed according to the test method previously described in the chemical tests in the Untreated Sediment Characterization section. 


\section{Discussion of Results}

\section{Characterization Results for Untreated Sediment}

As discussed in the Materials and Methods section of this report, samples that were used to characterize the untreated sediment were subjected to various physical and chemical tests. The results of the physical tests are summarized in Table 2. The raw physical tests results for the untreated sediment characterization are presented in Appendix A. The purpose of this initial characterization is twofold. First, engineering properties of the sediment are measured to provide data that describe the sediment, and secondly, baseline data are collected for the untreated sediment to provide a basis of comparison for the various treatments applied.

\begin{tabular}{|c|c|}
\hline \multicolumn{2}{|c|}{$\begin{array}{l}\text { Table } 2 \\
\text { Average Results of Physical Tests Conducted on Untreated } \\
\text { Sediment }\end{array}$} \\
\hline Moisture content & 68.6 percent \\
\hline $\begin{array}{l}\text { Bulk density at } \\
\text { 68.6-percent moisture } \\
\text { 60-percent moisture }\end{array}$ & $\begin{array}{l}79.8 \mathrm{lb} / \mathrm{ft}^{3} \\
77.0 \mathrm{lb} / \mathrm{ft}^{3}\end{array}$ \\
\hline Proctor density & $94.6 \mathrm{lb} / \mathrm{ft}^{3}$ \\
\hline Unconfined compressive strength & $45 \mathrm{lb} / \mathrm{in}^{2}$ \\
\hline Resistance to penetration & $145 \mathrm{lb} / \mathrm{in} .^{2}$ \\
\hline Specific gravity & 2.44 \\
\hline $\begin{array}{l}\text { Paint filter at } \\
\text { 68.6-percent moisture } \\
\text { 60-percent moisture }\end{array}$ & $\begin{array}{l}\text { Failed } \\
\text { Passed }\end{array}$ \\
\hline
\end{tabular}

Although little discussion is needed for Table 2, it should be noted that the bulk density and paint filter test for the sediment were taken at two moisture contents. These two moisture contents, 68.6-percent and 60-percent moisture, were used in the preparation of samples for the IST. The results of the paint filter test are expressed as either "pass" or "fail." If the sample "passed" the paint filter test, this means that no free liquid was observed to filter through 
the paint filter from the sample. If the sediment sample "failed" the paint filter test, free liquid was observed to be present in the sediment sample.

Table 2 indicates that the UCS for the sediment falls below the USEPA recommended 50-psi criteria (USEPA 1986a). Thus the sediment material cannot be solidified (achieve physical integrity) simply by compaction at the optimal moisture content.

Atterberg limits for the untreated sediment indicated that the liquid limit, plastic limit, and plasticity index is 98,49 , and 49 , respectively. The grainsize analysis of the sediment shows that 16.1 percent of the sediment is sand and 83.9 percent of the sediment is fine particles. Graphs of the grain-size analysis are presented in Appendix A. Based on the grain-size analysis, the sediment is classified as a sandy organic clay $(\mathrm{OH})$.

Two chemical tests were used to chemically characterize the untreated sediment: bulk chemical analysis and the TCLP. Triangle Laboratory performed the chemical analyses of the bulk untreated sediment. The results of these tests for the sediment are presented in Tables 3-7.

\begin{tabular}{||l|l|}
\hline \multicolumn{2}{||l|}{$\begin{array}{l}\text { Table 3 } \\
\text { Average Bulk Chemical Analysis of Untreated Sediment } \\
\text { Organochlorine Pesticides (OCPs) }\end{array}$} \\
\hline \hline Analytes & Concentration, $\mu \mathrm{g} / \mathrm{kg}$ \\
\hline \hline BHC & ND' \\
\hline Chlordane & ND \\
\hline Aldrin & 75.0 \\
\hline B-BHC & ND \\
\hline A-BHC & ND \\
\hline $4,4-D D D$ & 162.1 \\
\hline $4,4-D D E$ & 150.6 \\
\hline $4,4-D D T$ & ND \\
\hline Dieldrin & 74.5 \\
\hline Endrin & ND \\
\hline Endoaldehyde & ND \\
\hline Endosulfan I & ND \\
\hline Endosulfan II & ND \\
\hline Endosulfate & ND \\
\hline Lindane & ND \\
\hline g-Chlordane & ND \\
\hline Heptachlor & ND \\
\hline Heptachlor-epoxide & ND \\
\hline Methocychlor & ND \\
\hline Toxaphene & ND \\
\hline \hline N ND = Analyte was not detected in sample. & \\
\hline & \\
\hline
\end{tabular}




\begin{tabular}{|l|c|}
\hline \multicolumn{2}{|l|}{$\begin{array}{l}\text { Table 4 } \\
\text { Average Bulk Chemical Analysis of Untreated Sediment, PAHs } \\
\end{array}$} \\
\hline \hline Analytes & Concentration, $\mu \mathrm{g} / \mathrm{kg}$ \\
\hline \hline Phenol & 585 \\
\hline 3,4-Methylphenol & 1,390 \\
\hline Naphthalene & 2,729 \\
\hline 4-chloroanilime & 1,003 \\
\hline 2-Methylnaphthalene & 2,304 \\
\hline Acenaphthylene & 1,289 \\
\hline Acemaphthene & 1,042 \\
\hline Dibenzofuran & 1,172 \\
\hline Fluorene & 1,389 \\
\hline Phenanthrene & 6,586 \\
\hline Anthracene & 3,702 \\
\hline Di-n-butylphthalate & 1,227 \\
\hline Fluoranthene & 10,324 \\
\hline Pyrene & 7,101 \\
\hline Butylbenzylphthalete & 1,473 \\
\hline 6,3,2-ethylbenzylphthalete & 48,631 \\
\hline Benzo(a)anthracene & 4,484 \\
\hline Chrysene & 4,564 \\
\hline Di-n-octylphthalete & 3,523 \\
\hline Benzo(b)fluoranthene & 2,922 \\
\hline Benzo(k)fluoranthene & 1,107 \\
\hline Benzo(a)pyrene & 2,551 \\
\hline Indeno(1,2,3-rd)pyrene & 1,076 \\
\hline dibenzo(a,h)anthracene & 397 \\
\hline Benzo(g,h,i)perylene & 1,254 \\
\hline Benzo(e)pyrene & \\
\hline Perylene & \\
\hline \hline PAHs = Polycyclic aromatic hydrocarbons. & \\
\hline
\end{tabular}

The TCLP of the untreated NY/NJ Harbor sediment was performed by Triangle Laboratories. The results of the TCLP test performed on the untreated sediment are presented in Appendix A. The results of the TCLP performed on the untreated sediment show that none of the compounds found in the sediment were leached above the detection limit from the sample except 


\begin{tabular}{||l|c|}
\hline \multicolumn{2}{||l|}{$\begin{array}{l}\text { Table 5 } \\
\text { Average Bulk Chemical Analysis of Untreated Sediment, Metals }\end{array}$} \\
\hline \hline Analytes & Concentration, $\mathbf{~ g} / \mathrm{kg}$ \\
\hline Silver & 18.4 \\
\hline Arsenic & 33.5 \\
\hline Beryllium & $<0.58$ \\
\hline Cadmium & 37.1 \\
\hline Chromium & 377 \\
\hline Copper & 1,172 \\
\hline Nickel & 297 \\
\hline Lead & 617 \\
\hline Antimony & 10.3 \\
\hline Selenium & 3.24 \\
\hline Thalium & $<2.8$ \\
\hline Zinc & 1,725 \\
\hline Mercury & 1.29 \\
\hline
\end{tabular}

for chromium. The average chromium concentration found in the TCLP leachate was $0.03 \mathrm{mg} / \mathrm{l}$. The results of the TCLP suggest that the contaminants found in the New York/New Jersey Harbor sediment exhibit limited leachability from the sediment.

\section{Initial Screening Test}

The results of the CI for the IST are presented in Figures 2 and 3 for the cement and lime/fly ash binders, respectively. The raw IST data for the CI tests are also presented in Appendix B. As discussed in the Materials and Methods section of this report, the IST evaluated two WSRs (68.6-percent and 60 -percent moisture content of the sediment) and three BSRs for each binder.

Figures 2 and 3 are plots of cure time versus CI for the sediment and all binders evaluated in the IST. These figures illustrate that as the WSR is increased, there is a general trend for the rate of strength development to decrease. This is true for both binders evaluated. Another expected trend that is exhibited in the IST and shown in these figures is that as the binder ratio is increased, the rate of strength development increases.

Figure 2 presents the $\mathrm{CI}$ for the sediment that was treated with the cement binder at two moisture contents of 68.6-percent and 60-percent moisture. The $\mathrm{CI}$ for both moisture contents evaluated shows that the $\mathrm{CI}$ increases as the 


\begin{tabular}{|c|c|}
\hline \multicolumn{2}{|c|}{$\begin{array}{l}\text { Table } 6 \\
\text { Average Bulk Chemical Analysis of Untreated Sediment, PCBs }\end{array}$} \\
\hline Analytes & Concentration, $\mu \mathrm{g} / \mathrm{kg}$ \\
\hline 2-mono-CB & 57 \\
\hline 4,4-DiCB & 65 \\
\hline 2,4,4-TriCB & 168 \\
\hline 2,2,5,5-TetraCB & 269 \\
\hline 3,3,4,4-TetraCB & 14 \\
\hline 2,3,4,4,5-PentaCB & 6 \\
\hline 2,3,3,4,4-PentaCB & 67 \\
\hline 3,3,4,4,5-PentaCB & 0.4 \\
\hline $2,3,3,4,4,5-$ HexaCB & 17 \\
\hline $3,3,4,4,5,5$ - НехаСB & ND \\
\hline 2,2,3,4,4,5,5-HeptaCB & 74 \\
\hline $2,2,3,3,4,4,5,5-$ OctaCB & 17 \\
\hline $2,2,3,3,4,4,5,5,6$-NonaCB & 12 \\
\hline DecaCB & 7 \\
\hline Total MonoCB & 109 \\
\hline Total DiCB & 379 \\
\hline Total TricB & 728 \\
\hline Total TetraCB & 1,588 \\
\hline Total PentaCB & 1,237 \\
\hline Total HexaCB & 809 \\
\hline Total HeptaCB & 295 \\
\hline Total OctaCB & 96 \\
\hline Total NonaCB & 20 \\
\hline
\end{tabular}

BSR is increased. All of the cement BSRs evaluated showed low strength development during the first $8 \mathrm{hr}$ of cure. The 24-hr CI for most samples prepared showed substantial strength development as compared with the 8-hr CI reading. The only sample to achieve the maximum strength development after $24 \mathrm{hr}$ of cure was the 0.7 cement binder with a 60 -percent moisture content. The 0.7 cement binder/68.8-percent moisture sample and the 0.4 cement binder/60-percent moisture sample achieved the maximum CI of $750 \mathrm{psi}$ after $48 \mathrm{hr}$ of cure. Both samples prepared using the 0.1 cement BSR produced very little strength during the 48 -hr cure time for the $\mathrm{CI}$ test. 


\begin{tabular}{|c|c|}
\hline \multicolumn{2}{|c|}{$\begin{array}{l}\text { Table } 7 \\
\text { Average Bulk Chemical Analysis of Untreated Sediment Dioxins } \\
\text { and Furans }\end{array}$} \\
\hline Analytes & Concentration, ng/kg \\
\hline $2,3,7,8-T C D D$ & 40 \\
\hline 1,2,3,7,8-PeCDD & 57 \\
\hline $1,2,3,4,7,8-\mathrm{H} \times \mathrm{CDD}$ & 56 \\
\hline $1,2,3,6,7,8-\mathrm{HxCDD}$ & 142 \\
\hline $1,2,3,7,8,9-\mathrm{H} \times \mathrm{CDD}$ & 139 \\
\hline $1,2,3,4,6,7,8-\mathrm{HpCDD}$ & 2,022 \\
\hline OCDD & 17,453 \\
\hline $2,3,7,8-\mathrm{TCDF}$ & 340 \\
\hline 1,2,3,7,8-PeCDF & 311 \\
\hline $2,3,4,7,8-\mathrm{PeCDF}$ & 152 \\
\hline $1,2,3,4,7,8-\mathrm{HxCDF}$ & 1,303 \\
\hline $1,2,3,6,7,8-\mathrm{HxCDF}$ & 454 \\
\hline $2,3,4,6,7,8-\mathrm{H} \times \mathrm{CDF}$ & 184 \\
\hline $1,2,3,7,8,9-\mathrm{H} \times C D F$ & 25 \\
\hline $1,2,3,4,6,7,8-\mathrm{HpCDF}$ & 4,958 \\
\hline 1,2,3,4,7,8,9-HpCDF & 110 \\
\hline OCDF & 4,418 \\
\hline \multicolumn{2}{|c|}{ Total Dioxins } \\
\hline Total TCDD & 248 \\
\hline Total PeCDD & 378 \\
\hline Total HXCDD & 1,370 \\
\hline Total HpCDD & 4,450 \\
\hline \multicolumn{2}{|c|}{ Total Furans } \\
\hline Total TCDF & 2,371 \\
\hline Total PeCDF & 2,853 \\
\hline Total HxCDF & 5,175 \\
\hline Total HpCDF & 6,068 \\
\hline
\end{tabular}

Figure 3 presents the $\mathrm{CI}$ for the sediment that was treated with the lime/fly ash binder at the two moisture contents of 68.6 percent and 60 percent. The $\mathrm{CI}$ for all samples prepared using the lime/fly ash binder indicates that none of the samples gained much strength during the 48-hr cure time. As expected, the 0.3/0.3 lime/fly ash BSR/60-percent moisture sample achieved the highest 


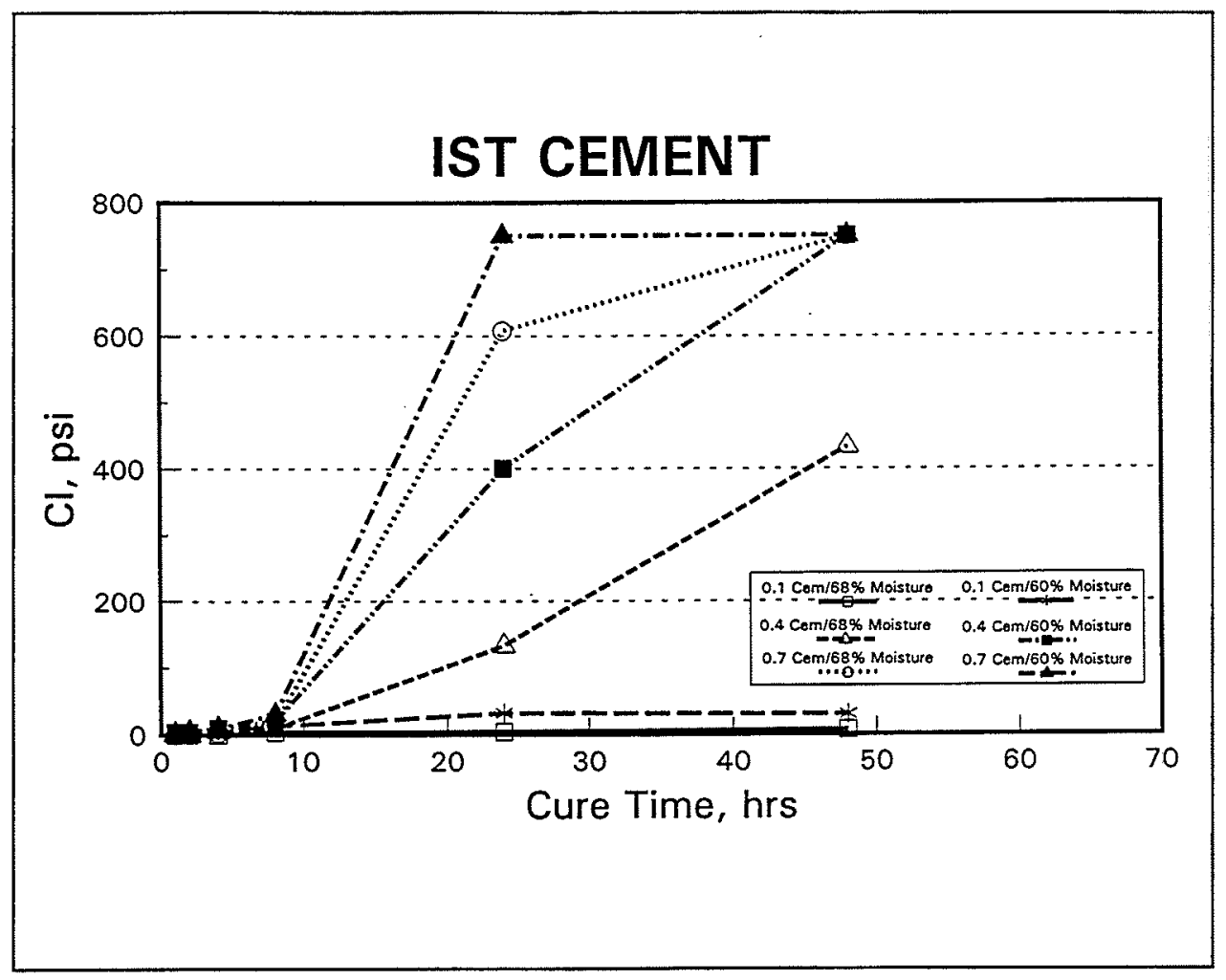

Figure 2. $\mathrm{Cl}$ results for IST cement binder

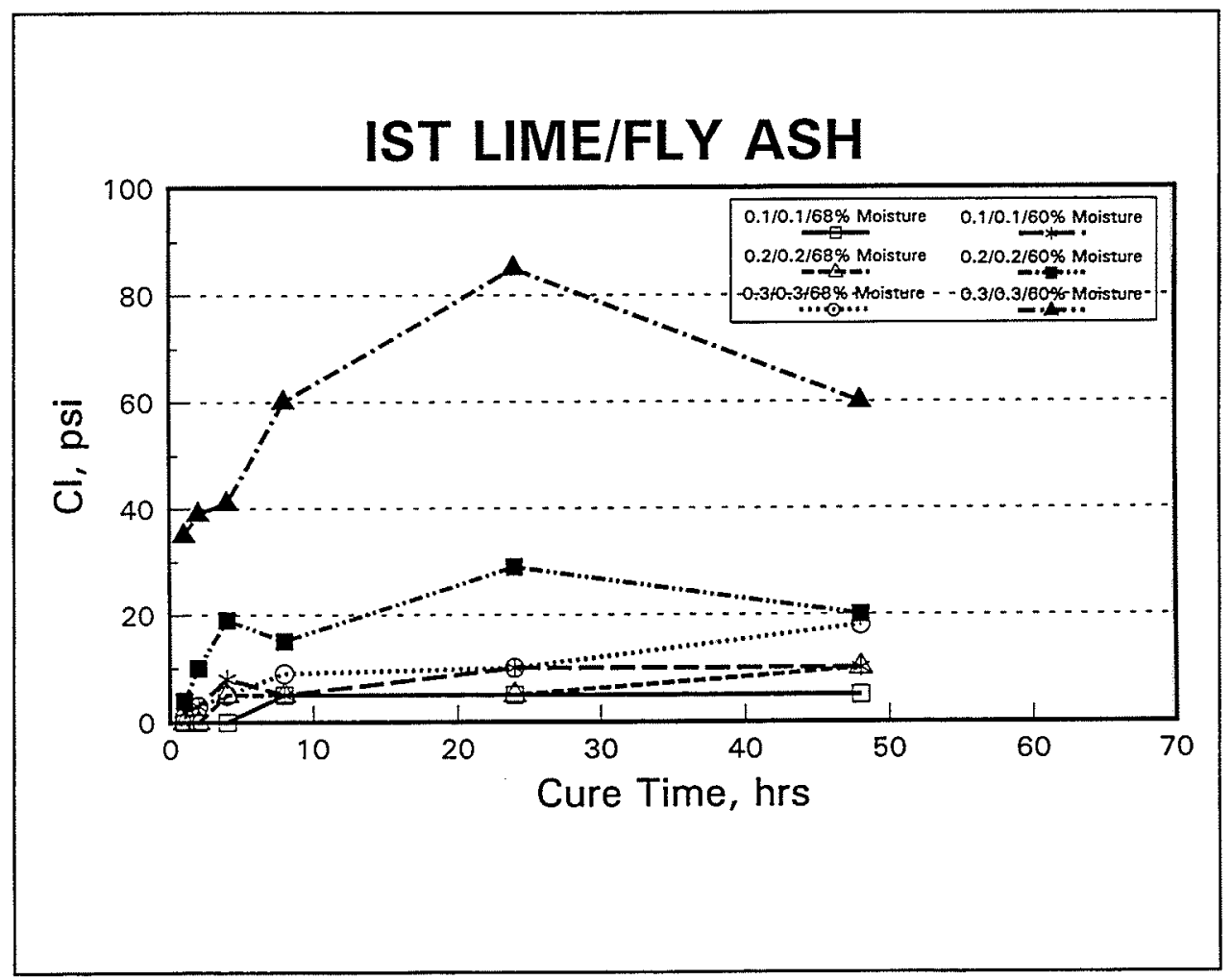

Figure 3. $\mathrm{Cl}$ results for IST lime/fly ash binder 
strength for the CI test. The remaining samples did not gain strength above 20 psi for the CI test.

The CI measurements for the IST were terminated after $48 \mathrm{hr}$ of cure. Based on previous tests (Bricka, Holmes, and Cullinane 1988; Channell and Kosson 1993; and Bricka and Jones 1993), a curing time of $48 \mathrm{hr}$ has proven to provide a rapid but useful tool to aid in the water ratio selection and narrow the binder ratios to be investigated during the detailed evaluation portion of the $\mathrm{S} / \mathrm{S}$ investigations. The average 48-hr CI results for the ISTs are presented in Table 8. Several of the samples exhibited very low $48-\mathrm{hr}$ CI values as reported in this table. Typically, low values are indicative of samples that developed a free liquid layer on the upper surface of the sediment/binder mixture after it had cured $48 \mathrm{hr}$. These samples did not develop water on the upper surface of the sample, but they did not develop substantial strength. This would present special handling problems because of the low strength development of the samples.

\begin{tabular}{|l|l|c|}
\hline $\begin{array}{l}\text { Table 8 } \\
\text { Average IST 48-Hr CI Data }\end{array}$ & WSR, Moisture Content, \% & 48-Hr Cl, psi \\
\hline \hline Binder Ratio & 68.6 & 7 \\
\hline 0.1 cement & 68.6 & 433 \\
\hline 0.4 cement & 68.6 & $>750$ \\
\hline 0.7 cement & 60 & 30 \\
\hline 0.1 cement & 60 & $>750$ \\
\hline 0.4 cement & 60 & $>750$ \\
\hline 0.7 cement & 68.6 & 5 \\
\hline $0.1 / 0.1$ lime/fly ash & 68.6 & 10 \\
\hline $0.2 / 0.2$ lime/fly ash & 68.6 & 18 \\
\hline $0.3 / 0.3$ lime fly ash & 60 & 10 \\
\hline $0.1 / 0.1$ lime/fly ash & 60 & 20 \\
\hline $0.2 / 0.2$ lime/fly ash & 60 & 60 \\
\hline $0.3 / 0.3$ lime fly ash & & \\
\hline
\end{tabular}

Free water formation generally occurs at the low binder/high water ratio mixtures. It is expected in cases where free water forms that the optimal water/binder ratio is far exceeded. Thus, excess water separates from the sediment and rises to the surface of the sample as a result of the settling of the heavier solids. Free water formation would be highly undesirable during the application of S/S processing and, thus, is generally avoided.

The CI results for the IST were considered in making a determination of the WSR and the range of BSRs to be used in the detailed evaluation portion 
of this study. In making this selection for the ratios to be considered for further evaluation, the criteria listed below are generally followed.

a. Ratios that exhibit free liquid formation are avoided.

b. Forty-eight-hour CI tests are maximized.

Using this criteria, the WSRs and BSRs selected for the detailed evaluation were $0.2,0.4,0.6$, and 0.8 portland cement using the moisture content of 60 percent and lime/fly ash ratios of $0.3 / 0.4,0.3 / 0.6,0.4 / 0.4$, and 0.4/0.6 using the 60 -percent moisture content of the sediment.

\section{Detailed Evaluation Results}

\section{Results of physical tests}

A combination of seven tests are utilized to measure the physical properties of the $\mathrm{S} / \mathrm{S}$ sediment in the detailed evaluation portion of this study. These tests included moisture content, bulk density, bleed water, cracking, UCS, CI, and workability (slump). The raw data generated from these tests are presented in Appendix C, and the results of each test are discussed below.

Moisture content. The results of the moisture content test for each BSR/ sediment mixtures are presented in Appendix C. The moisture content of the S/S samples varies between 36.8 percent and 19.9 percent for the samples solidified using the varying cement BSRs. The moisture content of the samples prepared using varying lime/fly ash BSRs had moisture contents varying between 24.3-percent and 19.1-percent moisture.

Bulk density. The results of the bulk density tests are presented in Appendix C. Bulk densities of the four cement binder samples varied between 73.4 and $103.4 \mathrm{lb} / \mathrm{ft}^{3}$. The lime/fly ash samples had bulk densities values between 77.6 and $85.3 \mathrm{lb} / \mathrm{ft}^{3}$. As expected, as the binder ratio is increased, the bulk density increases for the cement binder. The lime/fly ash samples showed that the 0.4/0.4 lime/fly ash sample had the highest bulk density. The bulk density of the untreated sediment at 60 -percent moisture content was $77 \mathrm{lb} / \mathrm{ft}^{3}$, and the Proctor density was $94.6 \mathrm{lb} / \mathrm{ft}^{3}$. Thus, most of the solidified samples have bulk densities higher than the bulk density of the untreated sediment but lower than the Proctor density.

Figures 4 and 5 present the increased volume of the treated sediment when compared with the untreated sediment compacted at the optimal water content using the standard compactive effort (Proctor density). The methods used to calculate the percent volume increase were described previously under the Materials and Methods section of this report.

Figure 4 shows that the cement BSRs of $0.2,0.4$, and 0.6 had volume increases averaging 55 to 57 percent. The 0.8 cement BSR had a volume 


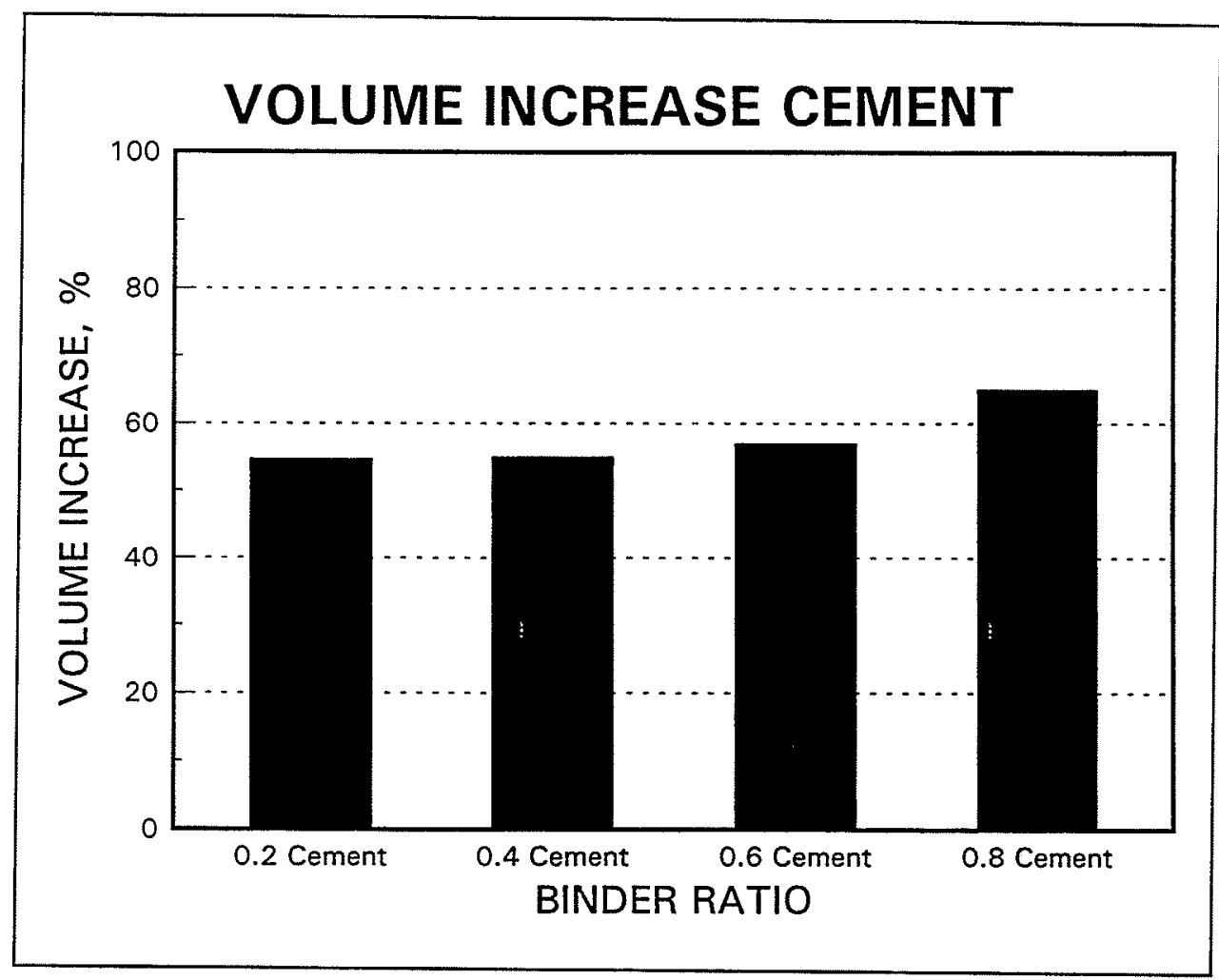

Figure 4. Percent volume increase of cement BSR samples

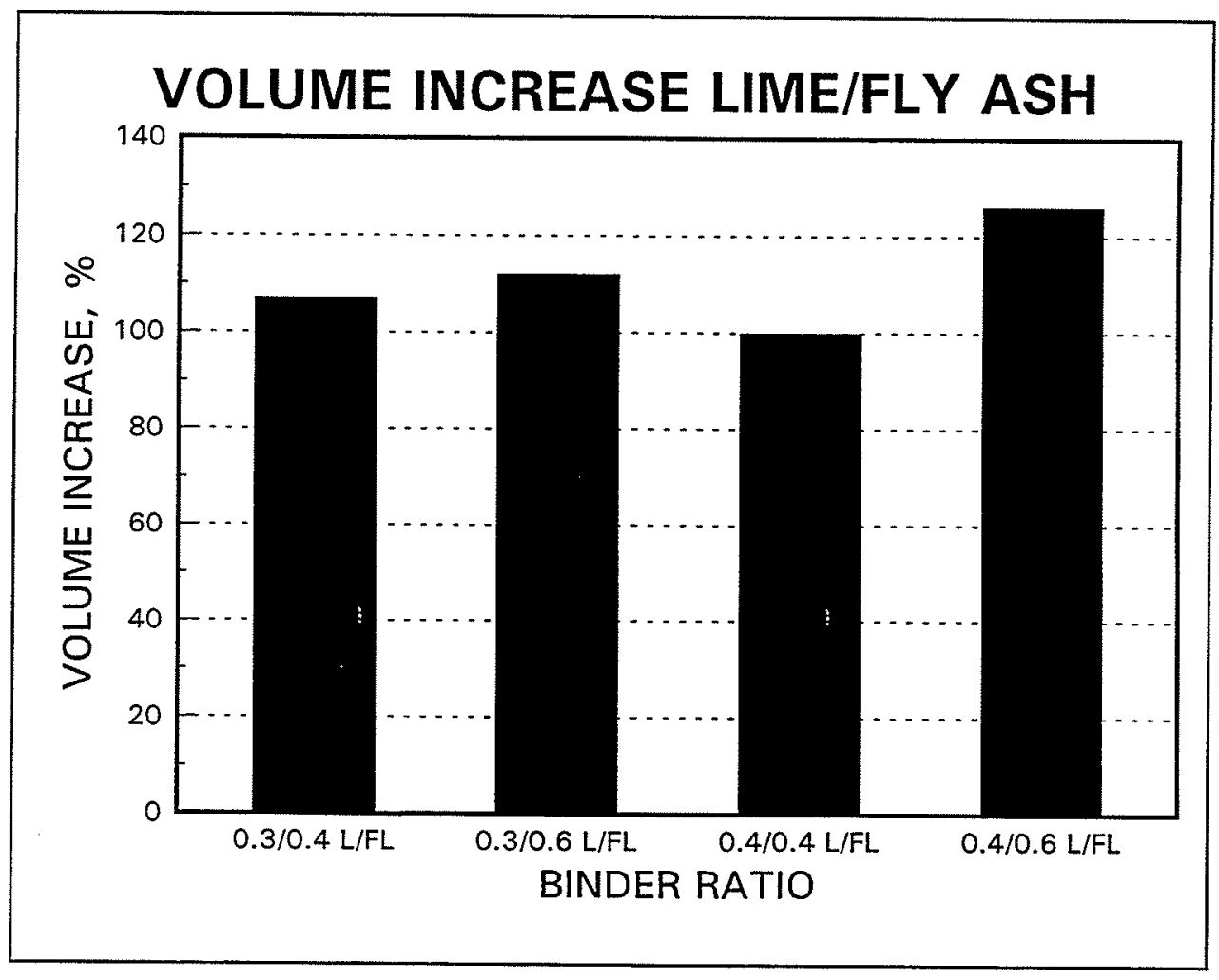

Figure 5. Percent volume increase of lime/fly ash BSR samples 
increase of 65 percent. In general, as the BSR was increased for the preparation of the sediment samples, the volume of the sample increased. Figure 5 shows that the lime/fly ash BSRs had volume increases ranging from 100 percent to 126 percent of the untreated sediment compacted at the optimal density. This volume increase of over 100 percent indicates that the sediment treated with the ratios of lime/fly ash used for this study will more than double the volume of the sediment.

Bleed water and cracking. All the specimens prepared were visually inspected for bleed water and cracking as described in the Materials and Methods section of this report. None of the samples prepared produced bleed water, and all samples were free from visual cracks. This is important because the generation of a large number of cracks could potentially increase the rate of leaching of the contaminants. The development of a large number of cracks could be an indication of sediment incompatibility with the binder material.

Cone Index. Results of the raw CI data for the detailed evaluation are presented in Appendix C. The data are averaged for the replicate samples (A, B, and C) and are presented in Figures 6 and 7 as the $\mathrm{CI}$ value (reported as pounds per square inch) versus the cure time in hours.

Figure 6 presents the data for the $\mathrm{CI}$ test for the cement binders used to treat the sediment. All ratios, except the 0.2 cement BSR, achieved the maximum CI of $750 \mathrm{psi}$ after $48 \mathrm{hr}$ of cure time. As indicated during the IST

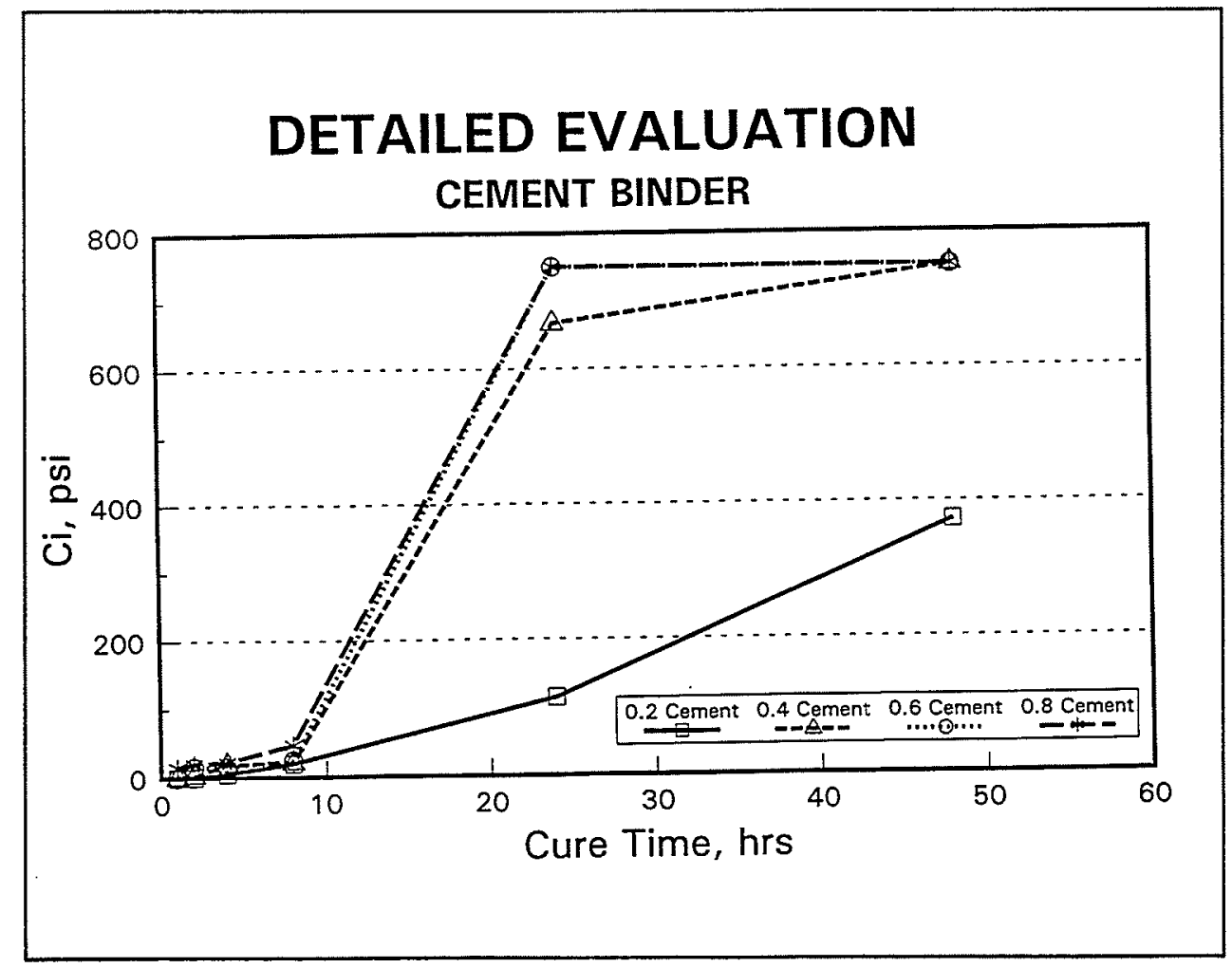

Figure 6. $\mathrm{Cl}$ test for cement BSR samples 


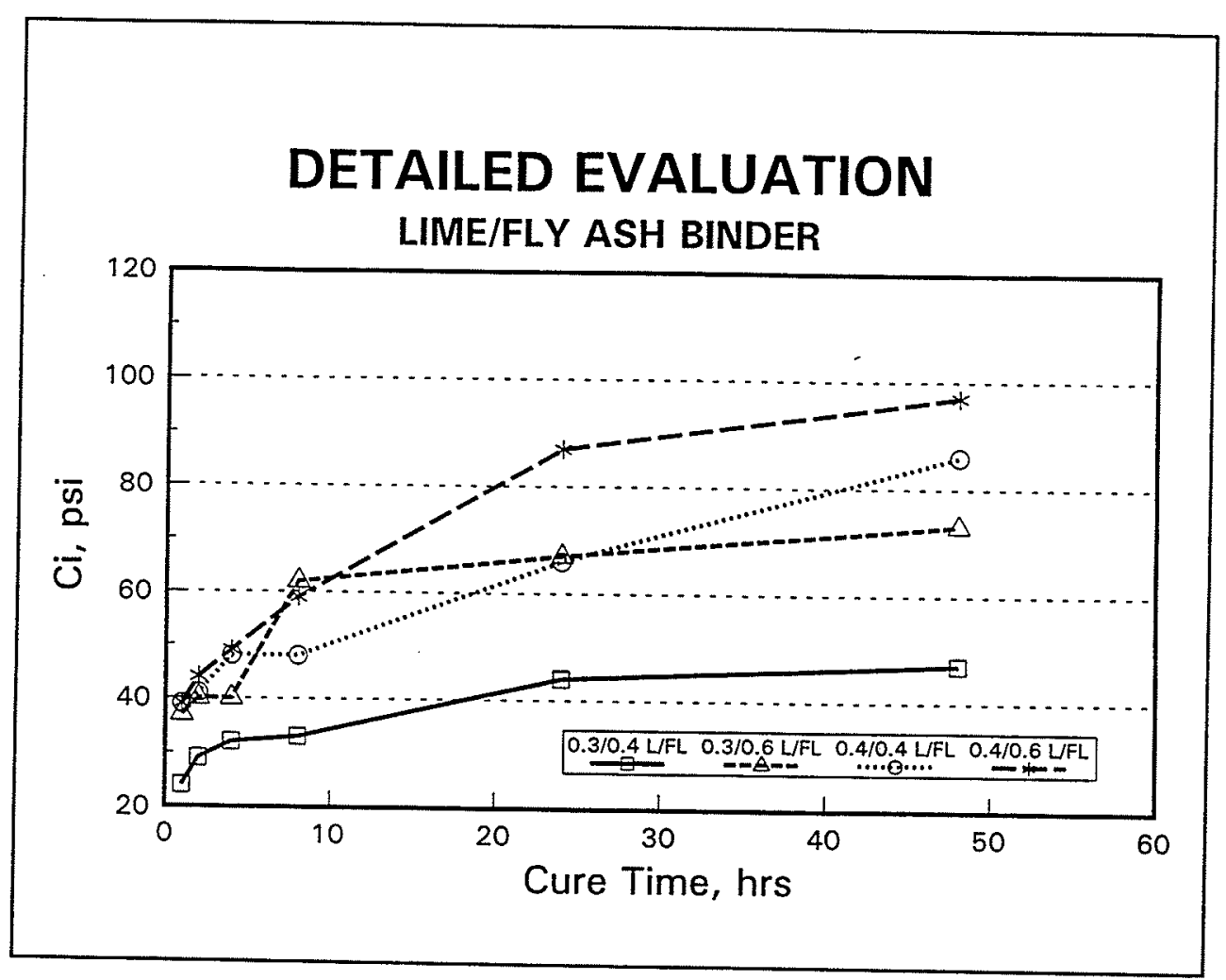

Figure 7. Cl test for lime/fly ash BSR samples

portion of the study, little strength development occurred during the initial $8 \mathrm{hr}$ of cure time. The 0.6 and 0.8 BSRs achieved the maximum CI of $750 \mathrm{psi}$ after only $24 \mathrm{hr}$ of cure. The 0.2 cement BSR also indicated strength development after the initial $8 \mathrm{hr}$ of cure, but only achieved a CI of $372 \mathrm{psi}$ after $48 \mathrm{hr}$ of cure.

Figure 7 presents the CI data for the lime/fly ash BSRs used to treat the New York/New Jersey Harbor sediment. Figure 7 shows that as the lime/fly ash BSR is increased, the 48-hr CI is increased. Although all samples showed the development of strength as the time was increased, the overall strength development was low. The lime/fly ash BSR of $0.4 / 0.6$ had the highest 48 -hr $\mathrm{CI}$ of all samples tested with a reading of $97 \mathrm{psi}$.

Unconfined compressive strength. Results of the raw UCS data for the detailed evaluation portion of this study are presented in Appendix C. The data were averaged for the replicate samples $(A, B$, and $C$ ), and these results are presented in Figures 8 and 9 as the UCS (reported as pounds per square inches) versus the cure time in days. A single line represents a binder ratio, and only one binder is presented per graph.

Figure 8 presents the UCS for the cement BSRs used to solidify the New York/New Jersey Harbor sediment. As expected, the data show that as the BSR is increased, the UCS increases for the samples prepared for the 


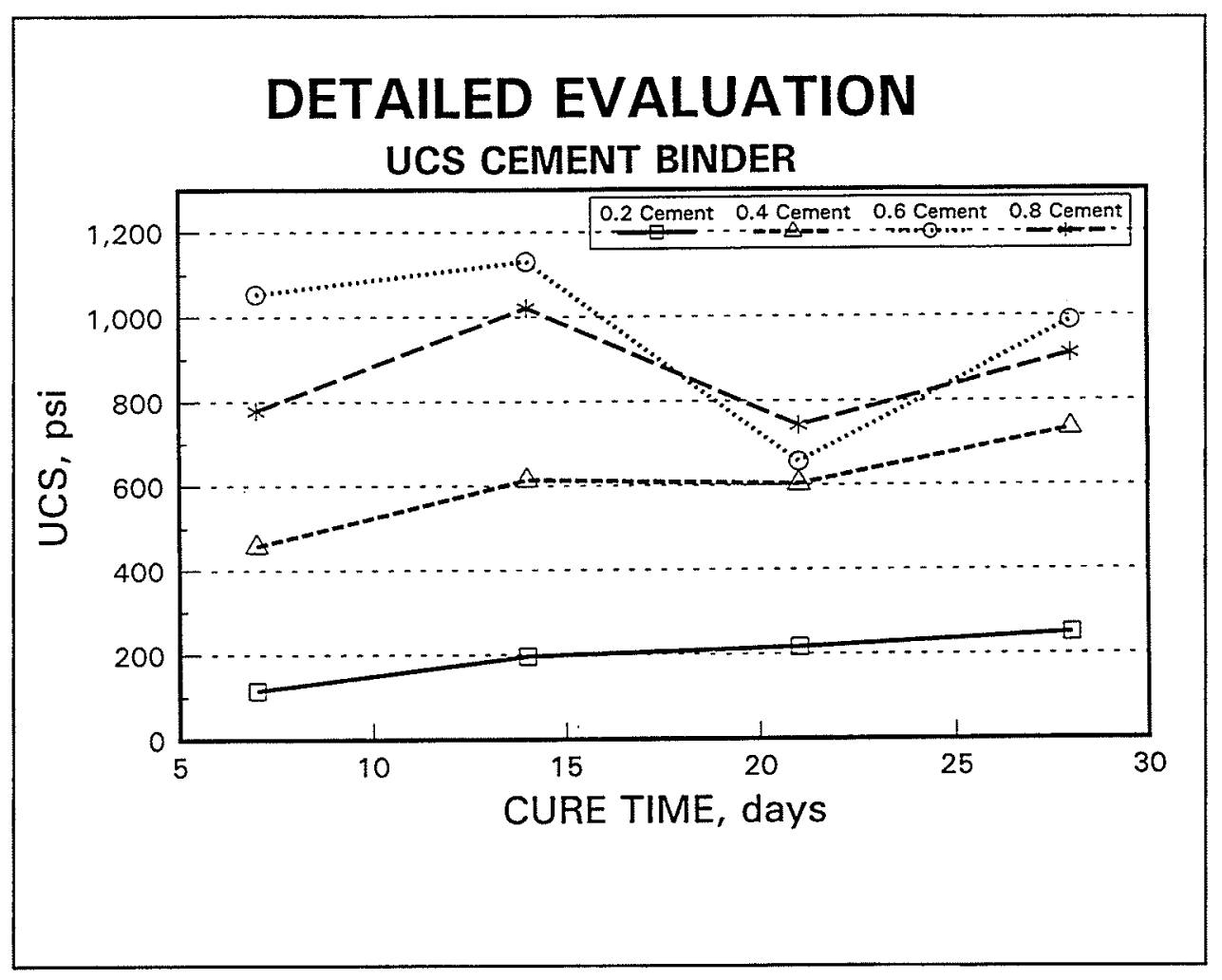

Figure 8. UCS for cement BSR samples

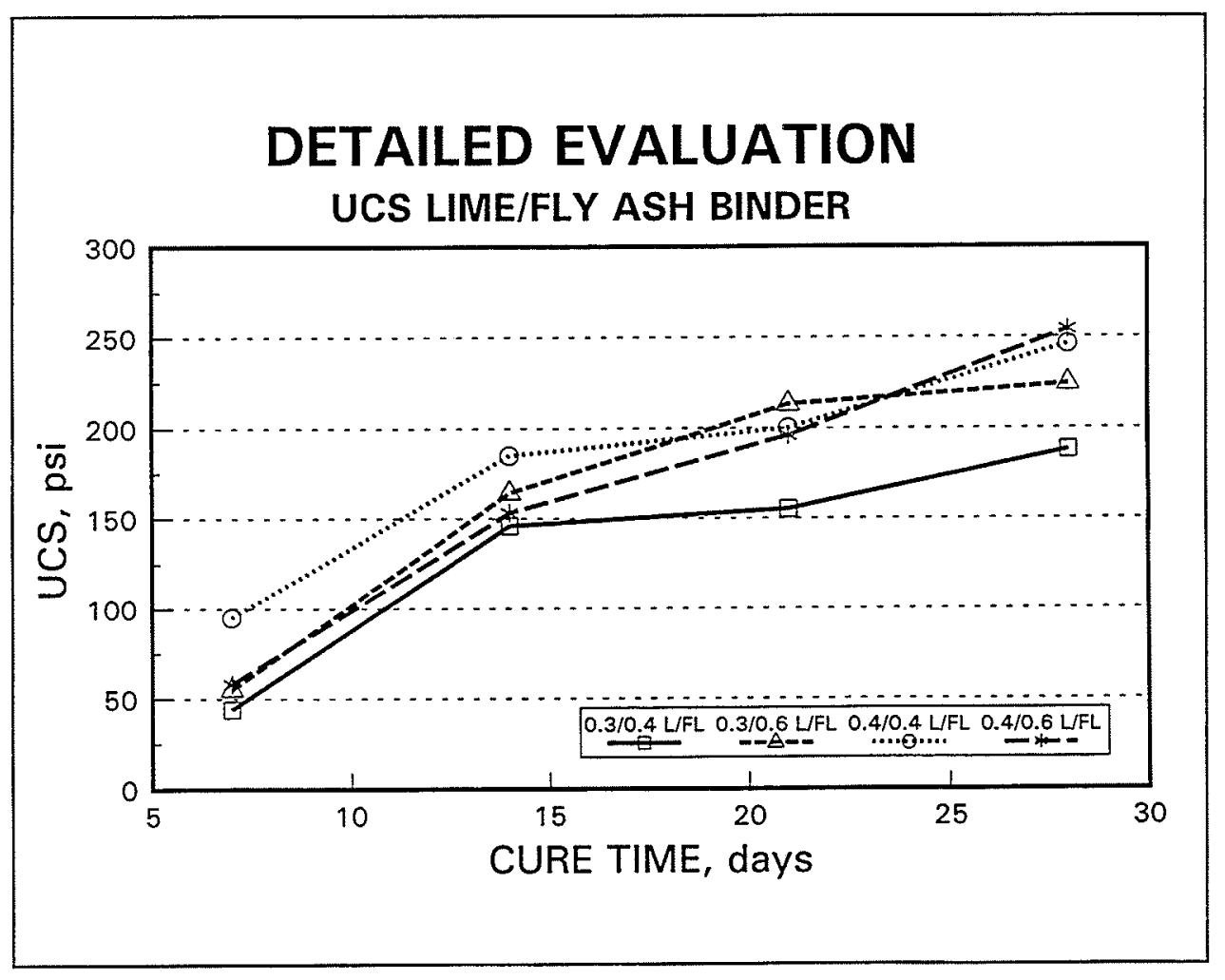

Figure 9. UCS for lime/fly ash BSR samples 
study. It should be noted that the samples prepared using the 0.6 and 0.8 cement BSRs contained voids in the samples that were tested. These voids caused the UCS to be lower for these BSRs and caused the data to be scattered as illustrated in Figure 8. All samples developed strengths in excess of the USEPA-recommended criteria of 50 psi (USEPA 1986b).

Figure 9 presents the UCS for the lime/fly ash BSRs used for the detailed evaluation portion of this study. As the lime/fly ash BSR was increased, the UCS values for the samples prepared for the study increased. All samples showed that as cure time increases, the UCS of the samples increased. All samples evaluated for UCS using the lime/fly ash BSRs showed that the USEPA-recommended strength of 50 psi was achieved after 28 days of cure. This is important because as defined by USEPA, all S/S treatments have evidence of a "chemical reaction."

Figures 10 and 11 present the 28-day UCS data as compared with the UCS for the untreated sediment compacted at 85 percent of their optimal proctor moisture. The data in these figures clearly indicate the $S / S$ is effective in increasing the 28-day strength for all the materials tested. The largest increases are observed for the high cement BSRs.

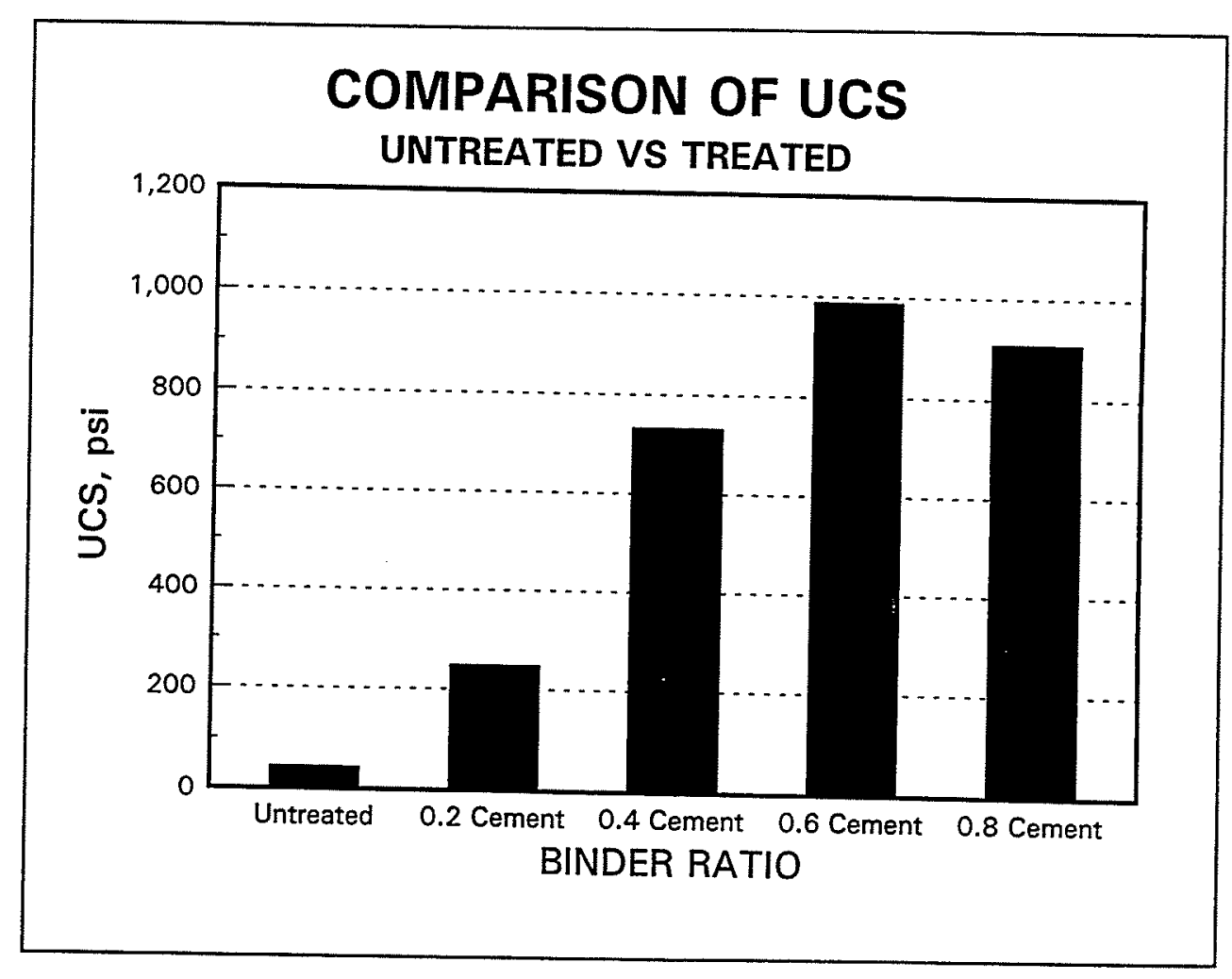

Figure 10. Comparison of UCS for untreated sediment and cement BSRS 


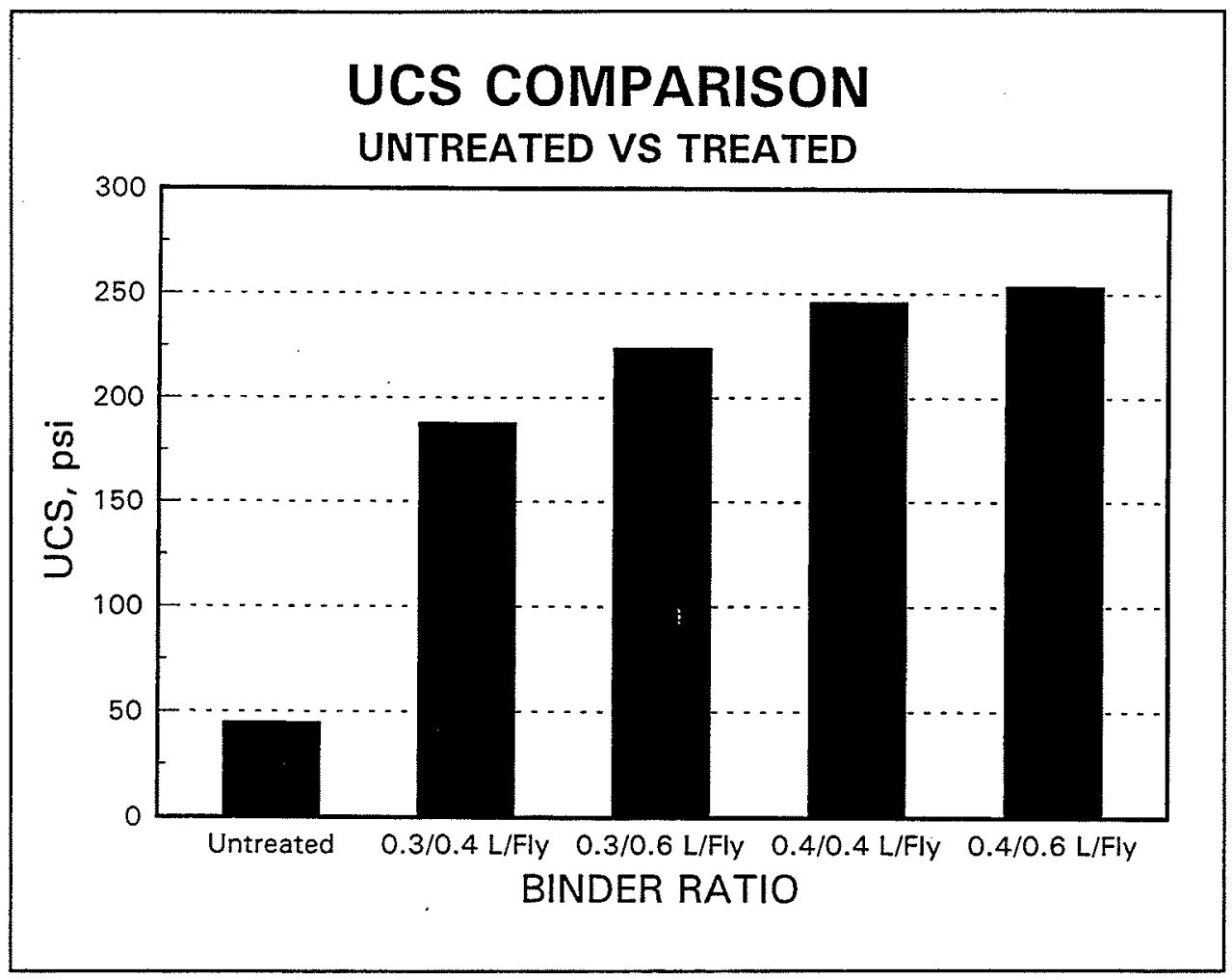

Figure 11. Comparison of UCS for untreated sediment and lime/fly ash BSRs

\section{Detailed evaluation chemical tests}

TCLP extractions were performed on Replicates A and B for each binder ratio used to solidify the New York/New Jersey Harbor sediment sample and on the untreated sediment. The TCLP extracts were analyzed for cadmium, chromium, copper, lead, mercury, nickel, and zinc. The results of the metals analyses were used to help determine the optimal formulation that would be selected and sent to Triangle Laboratories for further testing. Table 9 presents the metals results of the TCLP extracts.

The data from Table 9 show that the concentration of cadmium, chromium, lead, and mercury found in the TCLP leachate was well below the TCLP limits of $1.0,5.0,5.0$, and $0.02 \mathrm{mg} / \mathrm{l}$, respectively, for both the treated and untreated samples. The concentrations of cadmium, chromium, and lead were slightly above or below the detection limit used to analyze the TCLP leachate. Copper, nickel, and zinc were present in the TCLP leachate for all BSRs evaluated for the study. The results of the TCLP indicate that treatment of the sediment using cement and lime/fly ash increases the leachability of copper and nickel or the binders contributed to the contaminant concentrations in the leachate.

The TCLP analyses for the untreated sediment can be directly compared with the TCLP analyses for the solidified sediment if the data are normalized. 


\begin{tabular}{|l|l|l|c|c|c|c|c|c||}
\hline $\begin{array}{l}\text { Table 9 } \\
\text { Average Results of Metals for the TCLP for the Detailed Evaluation }\end{array}$ \\
\hline \hline Binder Addition & $\mathrm{Cd}, \mathrm{mg} / \mathrm{l}$ & $\mathrm{Cr}, \mathrm{mg} / \mathrm{l}$ & $\mathrm{Cu}, \mathrm{mg} / \mathrm{l}$ & $\mathrm{Pb}, \mathrm{mg} / \mathrm{l}$ & $\mathrm{Hg}, \mathrm{mg} / \mathrm{l}$ & $\mathrm{Ni}, \mathrm{mg} / \mathrm{l}$ & $\mathrm{Zn}, \mathrm{mg} / \mathrm{l}$ \\
\hline \hline Untreated & $<0.010$ & 0.091 & 0.011 & 0.076 & $<0.0002$ & 0.056 & 0.221 \\
\hline 0.2 Cement & $<0.005$ & $<0.010$ & 2.06 & 0.053 & 0.00080 & 0.305 & 0.152 \\
\hline 0.4 Cement & $<0.005$ & $<0.010$ & 1.24 & $<0.050$ & 0.00046 & 0.355 & 0.158 \\
\hline 0.6 Cement & $<0.005$ & $<0.010$ & 0.343 & $<0.050$ & 0.00028 & 0.159 & 0.140 \\
\hline 0.8 Cement & $<0.005$ & $<0.010$ & 0.426 & $<0.050$ & 0.00052 & 0.174 & 0.129 \\
\hline $0.3 / 0.4$ Lime/Fly Ash & $<0.005$ & $<0.009$ & 0.839 & 0.081 & 0.00025 & 0.235 & 0.199 \\
\hline $0.3 / 0.6$ Lime/Fly Ash & $<0.005$ & 0.011 & 0.579 & $<0.050$ & $<0.0002$ & 0.189 & 0.160 \\
\hline $0.4 / 0.4$ Lime/Fly Ash & $<0.005$ & $<0.009$ & 0.740 & 0.090 & 0.00021 & 0.197 & 0.206 \\
\hline $0.4 / 0.6$ Lime/Fly Ash & $<0.005$ & $<0.009$ & 0.655 & $<0.050$ & 0.00021 & 0.180 & 0.167 \\
\hline
\end{tabular}

The data were normalized to the TCLP extract concentration per weight of dry raw sediment extracted. The dilution of the raw sediment by the binder in the solidified sediment has been corrected. The TCLP contaminant mass/dry weight of sediment was derived using Equations 4-6.

$$
C d_{r}=\frac{C_{r}}{W_{r} \times M_{r}}
$$

where

$$
\begin{aligned}
& C d_{r}=\text { TCLP contaminant mass/dry weight untreated sediment, } \mathrm{mg} / \mathrm{g} \\
& \begin{aligned}
C_{r}= & \text { untreated sediment TCLP mass for contaminant of interest, } \mathrm{mg} \\
& \quad \text { (Calculated as: TCLP contaminant concentration, } \mathrm{mg} / \ell \times \mathrm{TCLP} \\
& \text { extraction solution volume, } \ell)
\end{aligned} \\
& W_{r}=\text { net weight of sediment (wet) extracted, } \mathrm{g} \\
& M_{r}= \\
& \quad \text { solids content of untreated sediment used in extraction expressed } \\
& \text { as a decimal } \\
& C d_{t}=\frac{C_{t}}{W_{t} \times M_{t} \times B_{t}}
\end{aligned}
$$


where

$$
\begin{aligned}
C d_{t}= & \text { TCLP contaminant mass/dry weight of sediment after } \mathrm{S} / \mathrm{S}, \mathrm{mg} / \mathrm{g} \\
C_{t}= & \text { S/S sediment TCLP mass for contaminant of interest, mg (calculated } \\
& \begin{array}{l}
\text { as: TCLP contaminant concentration, } \mathrm{mg} / \ell \times \mathrm{TCLP} \text { extraction } \\
\text { solution volume, } \ell)
\end{array} \\
W_{t}= & \text { weight of wet sediment, } \mathrm{g} \\
M_{t}= & \text { solids content of sediment used in } \mathrm{S} / \mathrm{S}, \text { expressed as a decimal } \\
B_{t}= & \text { weight fraction of sediment in S/S sediment calculated as follows: } \\
B_{t}= & \frac{\text { weight of sediment }}{\text { weight of sediment }+ \text { weight of binder }}
\end{aligned}
$$

\begin{tabular}{|c|c|c|c|c|c|c|c|}
\hline \multicolumn{8}{|c|}{$\begin{array}{l}\text { Table } 10 \\
\text { Normalized Results of TCLP }\end{array}$} \\
\hline Binder Addition & $\mathrm{Cd}$ & $\mathrm{Cr}$ & $\mathrm{Cu}$ & $\mathrm{Pb}, \mathrm{mg} / \mathrm{g}$ & $\mathrm{Hg}$ & $\mathrm{Ni}$ & $2 n$ \\
\hline Untreated & 0.00058 & 0.0053 & 0.00064 & 0.0044 & 0.00001 & 0.0033 & 0.0129 \\
\hline Maximum Possible & 0.0925 & 0.9425 & 2.930 & 1.5425 & 0.00323 & 0.7425 & 4.3125 \\
\hline 0.2 Cement & 0.00019 & 0.00038 & 0.0782 & 0.002 & 0.00003 & 0.0166 & 0.0058 \\
\hline 0.4 Cement & 0.0002 & 0.0004 & 0.0501 & 0.002 & 0.00002 & 0.0143 & 0.0064 \\
\hline 0.6 Cement & 0.0002 & 0.0004 & 0.0137 & 0.002 & 0.00001 & 0.0064 & 0.0056 \\
\hline 0.8 Cement & 0.00023 & 0.00046 & 0.0195 & 0.0029 & 0.00002 & 0.00797 & 0.0059 \\
\hline 0.3/0.4 Lime/Fly Ash & 0.00022 & 0.0004 & 0.0377 & 0.0036 & 0.00001 & 0.0106 & 0.0089 \\
\hline 0.3/0.6 Lime/Fly Ash & 0.00024 & 0.00052 & 0.0276 & 0.0024 & 0.00001 & 0.0090 & 0.0076 \\
\hline 0.4/0.4 Lime/Fly Ash & 0.00023 & 0.00042 & 0.0345 & 0.0042 & 0.00001 & 0.0092 & 0.0096 \\
\hline 0.4/0.6 Lime/Fly Ash & 0.00025 & 0.00044 & 0.0324 & 0.0025 & 0.00001 & 0.0089 & 0.0083 \\
\hline
\end{tabular}

Table 10 presents the normalized data for the untreated and treated sediment. When the contaminant was reported as less than the detection limit, the detection limit value was used for calculation of the normalized mass of contaminant in the sediment. Also Table 10 presents the maximum mass of contaminant that could be found in the leachate based on bulk sediment concentration and the TCLP dilution.

The results of the normalized data indicate the mass of contaminant that is leached for every gram of sediment. Cadmium, chromium, lead, and zinc all indicate that more of the metal is capable of leaching from the untreated sample than the treated sample for both cement and lime/fly ash. Copper and 
nickel indicate that more of the metal is leachable from the treated sample than the untreated sediment. Copper and nickel were leached at the highest concentrations from the sample prepared with the 0.2 cement binder. The amount of copper and nickel leached from the sample was a small percentage of the total maximum amount of the contaminant that could be leached from the sample. The amount of copper leached from the 0.2 cement sample was only 2.67 percent of the maximum amount of copper present in the sample that could leach while nickel was leached at 2.24 percent of the maximum amount of nickel present in the sample.

From the results of the physical tests and the TCLP performed at WES, two binder ratios were selected for further evaluation. These two binder ratios were 0.4 cement and 0.3/0.6 lime/fly ash. Samples of the NY/NJ Harbor sediment that had been treated with these two binders were sent to Triangle Laboratories for further evaluation. Triangle Laboratories performed the TCLP on the samples of 0.4 cement and 0.3/0.6 lime/fly ash. The results of TCLP performed by Triangle Laboratories are presented in Appendix C.

The results of the TCLP performed on the 0.4 cement and $0.3 / 0.6$ lime/fly ash samples indicated that most all of the results of the analysis were below the detection limit for all compounds. Barium was the only metal measured above the detection limit. The 0.3/0.6 lime/fly ash samples were the only samples to leach barium with concentrations of 0.7 and $0.9 \mathrm{mg} / \mathrm{\ell}$, respectively, for samples A and B. This concentration is well below the regulatory limit of $100 \mathrm{mg} / \ell$ for the TCLP. Polychlorinated biphenyls (PCBs) were detected in the TCLP leachate for both the 0.4 cement and the $0.3 / 0.6$ lime/fly ash samples. PCB homologue groups detected in the TCLP leachate were MonoCB, DiCB, TriCB, TetraCB, and PentaCB. The MonoCB compound had the highest concentration in both of the samples evaluated. MonoCB concentrations of $45 \mathrm{ppt}$ and $27 \mathrm{ppt}$ were observed in the cement and lime/fly ash samples, respectively. No volatile compounds, organochlorine pesticides, chlorinated herbicides, or semivolatile organic compounds were detected to leach from the solidified samples. For dioxins/furans analysis, there were two instances when MDLs were exceeded. 


\section{Conclusions}

The objective of this study was to evaluate if $S / S$ techniques can be applied to New York/New Jersey Harbor sediment to reduce the potential contaminant impact on the environment. This study has shown that common generic S/S binders can be applied to the New York/New Jersey Harbor sediment to alter the physical and chemical properties of the sediment.

Specific conclusions regarding the effects of the $S / S$ binder on the sediment are given below.

a. Cement and lime/fly ash S/S treatment of the New York/New Jersey Harbor sediment substantially increases the handling properties of the sediment.

b. The cement $\mathrm{S} / \mathrm{S}$ treatment was more effective in producing material that developed better physical properties than the lime/fly ash binder, although the sediment solidified with lime/fly ash developed materials that have good physical properties.

c. All BSRs evaluated for S/S increased the volume of the New York/ New Jersey Harbor sediment that must be handled.

d. The optimal binder formulation for the New York/New Jersey Harbor sediment was 0.4 cement and $0.3 / 0.6$ lime/fly ash.

$e$. The results of the TCLP performed on the optimal formulations indicated that $\mathrm{S} / \mathrm{S}$ reduced leachability for most contaminants evaluated.

f. The data from this study indicate that binder ratios of 0.4 cement and $0.3 / 0.6$ can effectively solidify/stabilize the New York/New Jersey Harbor sediment. 


\section{References}

American Society of Agronomy. (1965). "Methods for soil analysis: Part 1, Physical and mineralogical properties," Madison, WI.

American Society of Testing and Materials. (1987). Annual book of ASTM standards. Vol 04.01, Construction, Cement, Lime, Gypsum, Philadelphia, PA.

(1990). Annual book of ASTM standards. Vol 04.01, Construction, Cement, Lime, Gypsum, Philadelphia, PA.

- (1992a). Annual book of ASTM standards. Soil and Rock,

Dimension Stone, Geosynthetics, Philadelphia, PA.

. (1992b). Annual book of ASTM standards. Vol 04.01, Construction, Cement, Lime, Gypsum, Philadelphia, PA.

Bricka, R. M., Holmes, T., and Cullinane, M. J. (1988). “An evaluation of stabilization/solidification of fluidized bed incinerator ash (KO48 and KO51)," Technical Report EL-88-24, U.S. Army Engineer Waterways Experiment Station, Vicksburg, MS.

Bricka, R. M., and Jones, L. W. (1993). "An evaluation of factors affecting the solidification/stabilization of heavy metal sludge," Technical Report EL93-4, U.S. Army Engineer Waterways Experiment Station, Vicksburg, MS.

Channell, M. G., and Kosson, T. T. (1993). "An evaluation of stabilization/ solidification of an inorganic wood-preserving waste," Technical Report EL-93-10, U.S. Army Engineer Waterways Experiment Station, Vicksburg, MS.

Cullinane, M. J., Jr., Jones, L. W., and Malone, P. G. (1986). "Handbook for stabilization/solidification of hazardous waste," U.S. Environmental Protection Agency, EPA/540/2-86/001, Cincinnati, OH. 
Environmental Laboratory. (1987). "Disposal alternatives for PCBcontaminated sediments from Indiana Harbor, Indiana; Vol II," Miscellaneous Paper EL-87-9, U.S. Army Engineer Waterways Experiment Station, Vicksburg, MS.

Fleming, E. C., Averett, D. E., Channell, M. G., and Perry, B. D. (1991). "An evaluation of solidification/stabilization technology for Buffalo River sediment," Miscellaneous Paper EL-91-11, U.S. Army Engineer Waterways Experiment Station, Vicksburg, MS.

Headquarters, Department of the Army. (1971). "Materials testing," Technical Manual 5-530, Section XV, Washington, DC.

Kita, D., and Kube, H. (1983). "Several solidified sediment examples." Proceedings of the ninth annual U.S.IJapan experts meeting, management of bottom sediments containing toxic substances. U.S. Army Engineer Water Resources Support Center, Fort Belvoir, VA.

Malone, P. G., and Jones, L. W. (1979). "Guide to the disposal of chemically stabilized and solidified wastes," SW-872, Office of Water and Waste Management, U.S. Environmental Protection Agency, Cincinnati, OH.

Malone, P. G., Jones, L. W., and Larson, R. J. (1980). "Guide to the disposal of chemically stabilized and solidified wastes," SW-72, Office of Waste and Water Management, U.S. Environmental Protection Agency, Washington, DC.

Myers, T. E., and Zappi, M. E. (1989). "New Bedford Harbor Superfund Project, Acushnet River Estuary Engineering Feasibility Studies; Report 9, Laboratory-scale application of solidification/stabilization technology," Technical Report EL-88-15, U.S. Army Engineer Waterways Experiment Station, Vicksburg, MS.

Otsuki, T., and Shima, M. (1982). "Soil improvement by deep cement continuous mixing method and its effect on the environment." Proceedings of the eighth annual U.S.IJapan experts meeting, management of bottom sediments containing toxic substances. U.S. Army Engineer Water Resources Support Center, Fort Belvoir, VA.

Palermo, M. R., et al. (1989). "Evaluation of dredged material disposal alternatives for U.S. Navy Homeport at Everett, Washington," Technical Report EL-89-1. U.S. Army Engineer Waterways Experiment Station, Vicksburg, MS.

U.S. Army Corps of Engineers. (1970). "Laboratory soils testing," EM 11102-1906, Appendix VII, Washington, DC. 
U.S. Environmental Protection Agency. (1986a). Handbook for stabilization/ solidification of hazardous waste. Hazardous Waste Engineering Research laboratory, Cincinnati, $\mathrm{OH}$.

(1986b). "Prohibition on the placement of bulk liquid hazardous waste in landfills: Statutory interpretive guidance," EPA 530 SW-86-016, OSWER Policy Directive 9487.00-24, Office of Solid Waste and Emergency Response, Washington, DC. 


\section{Appendix A Physical/Chemical Tests Performed on Untreated Sediment}

\begin{tabular}{||l|l|}
\hline \hline \multicolumn{2}{||l|}{$\begin{array}{l}\text { Table A1 } \\
\text { Moisture Content of Untreated NY/NJ Harbor Sediment }\end{array}$} \\
\hline \hline Sample ID & Moisture Content, Percent \\
\hline \hline Drum 1-A & 69.7 \\
\hline Drum 1-B & 68.5 \\
\hline Drum 1-C & 69.5 \\
\hline Drum 2-A & 67.4 \\
\hline Drum 2-B & 67.0 \\
\hline Drum 2-C & 66.9 \\
\hline Drum 3-A & 70.0 \\
\hline Drum 3-B & 70.0 \\
\hline Drum 3-C & 69.1 \\
\hline Drum 4-A & 66.6 \\
\hline Drum 4-B & 68.6 \\
\hline Drum 4-C & 70.1 \\
\hline
\end{tabular}




\begin{tabular}{||l|l|l|l||}
\hline \hline \multirow{4}{*}{$\begin{array}{l}\text { Table A2 } \\
\text { Results of Physical Tests for Untreated NY/NJ Harbor Sediment }\end{array}$} \\
\hline \hline \multirow{3}{*}{ Physical Test } & \multicolumn{3}{|c|}{ Sediment Replicate } \\
\cline { 2 - 4 } & A & B & C \\
\hline \hline $\begin{array}{c}\text { Bulk density, lb/tit } \\
\text { 68.6-percent moisture } \\
\text { 60-percent moisture }\end{array}$ & 77.3 & 80.4 & 81.8 \\
\hline Proctor density, lb/tit & 78.0 & 75.4 & 77.6 \\
\hline UCS, psi & 94.6 & 91.0 & 93.5 \\
\hline Cl, psi & 46.4 & 40.4 & 50.5 \\
\hline Specific gravity & 140 & 150 & 145 \\
\hline $\begin{array}{l}\text { Paint fiter at } \\
\text { 68.6-percent moisture } \\
\text { 60-percent moisture }\end{array}$ & 2.44 & 2.45 & 2.44 \\
\hline \hline
\end{tabular}




\begin{tabular}{|c|c|c|c|c|c|c|}
\hline \multicolumn{7}{|c|}{$\begin{array}{l}\text { Table A3 } \\
\text { Bulk Chemistry of Untreated NY/NJ Harbor Sediment, PCBs' }\end{array}$} \\
\hline \multirow[b]{2}{*}{ Analyte } & \multicolumn{6}{|c|}{ Replicate Concentration, $\mu \mathrm{g} / \mathrm{kg}$} \\
\hline & 1 & 2 & 3 & 4 & 5 & 6 \\
\hline 2-mono-CB & 72 & 50 & 56 & 55 & 64 & 47 \\
\hline 4,4-DiCB & 79 & 59 & 62 & 63 & 73 & 52 \\
\hline 2,4,4-TricB & 193 & 157 & 187 & 153 & 186 & 133 \\
\hline 2,2,5,5-TetraCB & 308 & 237 & 235 & 220 & 406 & 210 \\
\hline 3,3,4,4-TetraCB & 16 & 12 & 13 & 13 & 19 & 10 \\
\hline 2,3,4,4,5-PentaCB & 8 & 5 & 6 & 5 & 7 & 5 \\
\hline 2,3,3,4,4-PentaCB & 77 & 54 & 68 & 57 & 86 & 58 \\
\hline 3,3,4,4,5-PentaCB & 0.6 & 0.4 & 0.4 & 0.4 & 0.6 & 0.2 \\
\hline $2,3,3,4,4,5-$ HexaCB & 19.7 & 14 & 21 & 15 & 18 & 15 \\
\hline $3,3,4,4,5,5-$ - $е x a C B$ & ND & ND & ND & ND & ND & ND \\
\hline $2,2,3,4,4,5,5$-HeptaCB & 90 & 63 & 76 & 72 & 79 & 82 \\
\hline $2,2,3,3,4,4,5,5-$ OctaCB & 20 & 16 & 17 & 16 & 18 & 16 \\
\hline $\begin{array}{l}2,2,3,3,4,4,5,5,6 \\
\text { NonaCB }\end{array}$ & 15 & 11 & 11 & 11 & 12 & 12 \\
\hline DecaCB & 10 & 6 & 7 & 7 & 8 & 8 \\
\hline \multicolumn{7}{|l|}{ TOTAL PCBs } \\
\hline Total MonoCB & 135 & 96 & 104 & 106 & 122 & 89 \\
\hline Total DiCB & 475 & 347 & 391 & 359 & 403 & 301 \\
\hline Total TriCB & 863 & 658 & 732 & 649 & 861 & 584 \\
\hline Total TetraCB & 1,860 & 1,570 & 1,400 & 1,330 & 2,130 & 1,240 \\
\hline Total PentaCB & 1,550 & 1,040 & 1,200 & 1,000 & 1,550 & 1,080 \\
\hline Total HexaCB & 974 & 668 & 946 & 688 & 865 & 712 \\
\hline Total HeptaCB & 363 & 249 & 308 & 285 & 318 & 246 \\
\hline Total OctaCB & 112 & 87 & 97 & 90 & 100 & 90 \\
\hline Total NonaCB & 25 & 18 & 19 & 19 & 21 & 19 \\
\hline
\end{tabular}




\begin{tabular}{|c|c|c|c|c|c|c|}
\hline \multicolumn{7}{|c|}{$\begin{array}{l}\text { Table A4 } \\
\text { Bulk Chemistry of Untreated NY/NJ Harbor Sediment, OCPs' }\end{array}$} \\
\hline \multirow[b]{2}{*}{ Analyte } & \multicolumn{6}{|c|}{ Replicate Concentration, $\mu \mathrm{g} / \mathrm{kg}$} \\
\hline & 1 & 2 & 3 & 4 & 5 & 6 \\
\hline $\mathrm{BHC}$ & $N D^{2}$ & ND & ND & ND & ND & ND \\
\hline Chlordane & ND & ND & ND & ND & ND & ND \\
\hline Aldrin & 85.8 & 64.6 & 79.3 & 65.7 & 53.3 & 101.3 \\
\hline beta-BHC & ND & ND & ND & ND & ND & ND \\
\hline delta-BHC & ND & ND & ND & ND & ND & ND \\
\hline 4,4-DDD & 161.5 & 130.6 & 178.1 & 149.1 & 113.3 & 240.0 \\
\hline 4,4-DDE & 158.1 & 126.1 & 185.6 & 117.5 & 92.8 & 223.3 \\
\hline 4,4-DDT & ND & ND & ND & ND & ND & ND \\
\hline Dieldrin & 78.1 & 57.3 & 83.7 & 65.9 & 48.1 & 113.6 \\
\hline Endrin & ND & ND & ND & ND & ND & ND \\
\hline Endoaldehyde & ND & ND & ND & ND & ND & ND \\
\hline Endosulfan 1 & ND & ND & ND & ND & ND & ND \\
\hline Endosulfan II & ND & ND & ND & ND & ND & ND \\
\hline Endosulfate & ND & ND & ND & ND & ND & ND \\
\hline Lindane & ND & ND & ND & ND & ND & ND \\
\hline g-Chlordane & ND & ND & ND & ND & ND & ND \\
\hline Heptachlor & ND & ND & ND & ND & ND & ND \\
\hline Heptachlor-expoxide & ND & ND & ND & ND & ND & ND \\
\hline Methoxychlor & ND & ND & ND & ND & ND & ND \\
\hline Toxaphene & ND & ND & ND & ND & ND & ND \\
\hline
\end{tabular}




\begin{tabular}{|c|c|c|c|c|c|c|}
\hline \multicolumn{7}{|c|}{$\begin{array}{l}\text { Table A5 } \\
\text { Bulk Chemistry of Untreated NY/NJ Harbor Sediment, PAHs' }\end{array}$} \\
\hline \multirow[b]{2}{*}{ Analyte } & \multicolumn{6}{|c|}{ Replicate Concentration, $\mu \mathrm{g} / \mathrm{kg}$} \\
\hline & 1 & 2 & 3 & 4 & 5 & 6 \\
\hline Phenol & 1,176 & 503 & 373 & 365 & 581 & 512 \\
\hline 3,4-Methylphenol & 1,275 & 1,218 & 1,705 & 1,305 & 1,599 & 1,236 \\
\hline Naphthalene & 2,639 & 2,814 & 2,569 & 3,126 & 2,738 & 2,486 \\
\hline 4-chloroanilime & 1,053 & 1,084 & 946 & 784 & 1,124 & 1,026 \\
\hline 2-Methylnaphthalene & 2,380 & 2,312 & 1,894 & 2,386 & 2,417 & 2,435 \\
\hline Acenaphthylene & 1,427 & 1,255 & 1,100 & 1,213 & 1,420 & 1,316 \\
\hline Acemaphthene & 981 & 1,050 & 879 & 1,089 & 1,149 & 1,106 \\
\hline Dibenzofuran & 1,357 & 1,250 & 994 & 1,125 & 1,143 & 1,153 \\
\hline Fluorene & 1,529 & 1,458 & 1,200 & 1,342 & 1,537 & 1,269 \\
\hline Phenanthrene & 7,229 & 6,911 & 5,453 & 6,263 & 6,927 & 6,733 \\
\hline Anthracene & 4,862 & 3,772 & 3,005 & 3,315 & 3,765 & 3,494 \\
\hline Di-n-butylphthalate & 1,372 & 927 & 1,811 & 1,233 & NS & 790 \\
\hline Fluoranthene & 11,263 & 10,846 & 8,060 & 9,511 & 11,758 & 10,504 \\
\hline Pyrene & 7,382 & 7,403 & 5,888 & 6,551 & 7,669 & 7,717 \\
\hline Butylbenzylphthalete & 1,463 & 1,345 & 1,379 & 2,385 & 1,001 & 1,268 \\
\hline 6,3,2-ethylbenzylphthalete & 48,993 & 62,435 & 40,301 & 46,073 & 44,606 & 49,377 \\
\hline Benzo(a)anthracene & 5,165 & 4,717 & 3,741 & 4,118 & 4,454 & 4,710 \\
\hline Chrysene & 5,080 & 4,885 & 3,475 & 4,179 & 4,829 & 4,938 \\
\hline Di-n-octylphthalete & 853 & $N^{2}$ & NS & NS & 6,192 & NS \\
\hline Benzo(b)fluoranthene & 3,309 & 2,943 & 2,247 & 2,552 & 3,144 & 3,338 \\
\hline Benzo(k)fluoranthene & 1,127 & 947 & 928 & 1,035 & 1,377 & 1,230 \\
\hline Benzo(a)pyrene & 2,851 & 2,533 & 2,139 & 2,218 & 2,794 & 2,770 \\
\hline Indeno(1,2,3-rd)pyrene & 1,444 & 1,137 & 928 & 763 & 1,195 & 987 \\
\hline dibenzo(a,h)anthracene & 677 & 343 & $N S^{2}$ & 305 & 341 & 319 \\
\hline Benzo(g,h,i)perylene & 1,743 & 1,461 & 1,225 & 694 & 1,221 & 1,182 \\
\hline Benzo(e)pyrene & 2,430 & 2,126 & 1,672 & 1,900 & 2,327 & 2,298 \\
\hline Perylene & 1,152 & 899 & 829 & 803 & 1,023 & 985 \\
\hline
\end{tabular}




\begin{tabular}{|c|c|c|c|c|c|c|}
\hline \multicolumn{7}{|c|}{$\begin{array}{l}\text { Table A6 } \\
\text { Bulk Chemistry of Untreated NY/NJ Harbor Sediment, Dioxins, } \\
\text { and Furans }\end{array}$} \\
\hline \multirow[b]{2}{*}{ Analyte } & \multicolumn{6}{|c|}{ Replicate Concentration, ng/kg } \\
\hline & 1 & 2 & 3 & 4 & 5 & 6 \\
\hline $2,3,7,8-T C D D$ & 43.1 & 37.4 & 36.6 & 43.6 & 40.5 & 43.6 \\
\hline 1,2,3,7,8-PeCDD & 42.9 & 44.4 & 42.8 & 50.9 & 104 & 119 \\
\hline $1,2,3,4,7,8-\mathrm{HxCDD}$ & 51.1 & 54.5 & 47.3 & 48.4 & 88.8 & 44.8 \\
\hline $1,2,3,6,7,8-\mathrm{HxCDD}$ & 131 & 139 & 120 & 146 & 180 & 134 \\
\hline 1,2,3,7,8,9-HxCDD & 137 & 157 & 120 & 146 & 166 & 108 \\
\hline 1,2,3,4,6,7,8-HpCDD & 2,040 & 2,300 & 2,070 & 2,170 & 2,190 & 1,780 \\
\hline OCDD & 17,080 & 21,150 & 16,320 & 18,070 & 15,930 & 16,230 \\
\hline 2,3,7,8-TCDF & 346 & 352 & 320 & 364 & 310 & 348 \\
\hline 1,2,3,7,8-PeCDF & 280 & 283 & 263 & 294 & 369 & 376 \\
\hline $2,3,4,7,8-\mathrm{PeCDF}$ & 135 & 151 & 133 & 161 & 181 & 152 \\
\hline $1,2,3,4,7,8 \cdot \mathrm{HxCDF}$ & 1,380 & 1,250 & 1,200 & 1,380 & 1,320 & 1,290 \\
\hline 1,2,3,6,7,8-HxCDF & 450 & 483 & 435 & 495 & 484 & 457 \\
\hline $2,3,4,6,7,8-\mathrm{HxCDF}$ & 191 & 193 & 163 & 187 & 207 & 165 \\
\hline $1,2,3,7,8,9-\mathrm{H} \times \mathrm{CDF}$ & 5.7 & 4.3 & 12.9 & 6.6 & 56.4 & 53.9 \\
\hline 1,2,3,4,6,7,8-HpCDF & 6,080 & 4,390 & 4,730 & 5,400 & 4,430 & 4,780 \\
\hline 1,2,3,4,7,8,9-HpCDF & 104 & 117 & 98.8 & 124 & 124 & 95.3 \\
\hline OCDF & 4,130 & 4,080 & 4,150 & 4,840 & 4,200 & 5,110 \\
\hline \multicolumn{7}{|l|}{ Total Dioxins } \\
\hline Total TCDD & 289 & 501 & 203 & 265 & 90.6 & 128 \\
\hline Total PeCDD & 314 & 640 & 375 & 451 & 320 & 169 \\
\hline Total HXCDD & 1,340 & 1,580 & 1,260 & 1,420 & 1,370 & 1,250 \\
\hline Total HpCDD & 4,240 & 4,970 & 4,340 & 4,620 & 4,510 & 4,020 \\
\hline \multicolumn{7}{|l|}{ Total Furans } \\
\hline Total TCDF & 2,300 & 2,370 & 2,450 & 2,790 & 1,970 & 1,990 \\
\hline Total PeCDF & 2,390 & 2,510 & 2,270 & 2,730 & 3,320 & 3,900 \\
\hline Total HXCDF & 5,420 & 4,960 & 4,800 & 5,700 & 5,130 & 5,040 \\
\hline Total HpCDF & 7,210 & 5,550 & 5,780 & 6,660 & 5,390 & 5,820 \\
\hline
\end{tabular}




\begin{tabular}{|c|c|c|c|c|c|c|}
\hline \multirow{2}{*}{ Analyte } & \multicolumn{6}{|c|}{ Replicate Concentration, $\mathrm{mg} / \mathrm{kg}$} \\
\hline & 1 & 2 & 3 & 4 & 5 & 6 \\
\hline Silver & 18.5 & 19.0 & 18.2 & 17.6 & 19.6 & 17.6 \\
\hline Arsenic & 32.5 & 33.5 & 33.1 & 32.3 & 39.1 & 30.4 \\
\hline Beryllium & $<0.55$ & $<0.58$ & $<0.53$ & $<0.55$ & $<0.56$ & $<0.58$ \\
\hline Cadmium & 36.7 & 39.4 & 36.2 & 35.8 & 38.6 & 35.6 \\
\hline Chromium & 374 & 399 & 371 & 366 & 396 & 354 \\
\hline Copper & 1,150 & 1,220 & 1,170 & 1,150 & 1,230 & 1,110 \\
\hline Nickel & 286 & 367 & 282 & 280 & 301 & 267 \\
\hline Lead & 564 & 581 & 638 & 602 & 666 & 653 \\
\hline Antimony & 9.82 & 13.1 & 10.0 & 8.72 & 10.6 & 9.5 \\
\hline Selenium & $<2.7$ & $<2.9$ & 5.02 & $<2.8$ & $<2.8$ & 3.19 \\
\hline Thallium & $<2.7$ & $<2.9$ & $<2.6$ & $<2.8$ & $<2.8$ & $<2.8$ \\
\hline Zinc & 1,710 & 1,760 & 1,680 & 1,870 & 1,730 & 1,600 \\
\hline Mercury (Total) & 1.22 & 1.29 & 1.27 & 1.35 & 1.38 & 1.22 \\
\hline
\end{tabular}




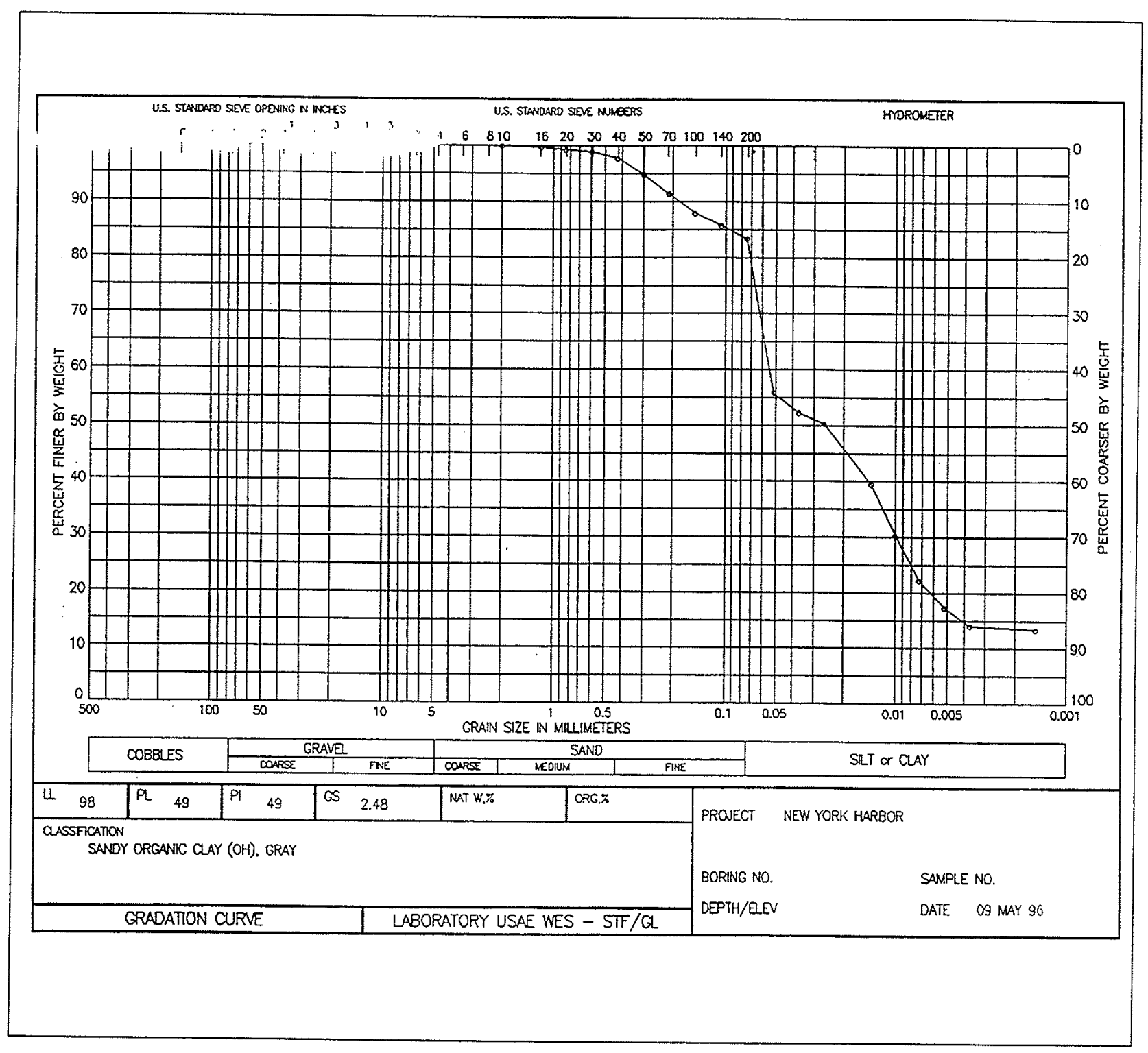

Figure A1. Grain-size curve for NY/NJ Harbor sediment 


\section{Appendix B Initial Screen Test Results}

\begin{tabular}{|c|c|c|c|c|c|c|c|}
\hline \multicolumn{8}{|c|}{$\begin{array}{l}\text { Table B1 } \\
\text { Cl Results of Cement Binders }\end{array}$} \\
\hline \multirow{2}{*}{$\begin{array}{l}\text { Binder } \\
\text { Ratio }\end{array}$} & \multirow[b]{2}{*}{ Replicate } & \multicolumn{6}{|c|}{ Cone Index, psi } \\
\hline & & $1 \mathrm{hr}$ & $2 \mathrm{hr}$ & $4 \mathrm{hr}$ & $8 \mathrm{hr}$ & $24 \mathrm{hr}$ & $48 \mathrm{hr}$ \\
\hline \multicolumn{8}{|c|}{ 68-Percent Moisture } \\
\hline \multirow[t]{3}{*}{0.1 Cement } & $A$ & 0 & 0 & 0 & 4 & 4 & 7 \\
\hline & $\mathrm{B}$ & 0 & 0 & 0 & 4 & 4 & 7 \\
\hline & $\mathrm{c}$ & 0 & 0 & 0 & 4 & 4 & 7 \\
\hline \multirow[t]{3}{*}{0.4 Cement } & $\mathrm{A}$ & 0 & 0 & 5 & 9 & 120 & 450 \\
\hline & $\mathrm{B}$ & 0 & 0 & 4 & 8 & 130 & 450 \\
\hline & $\mathrm{c}$ & 1 & 0 & 4 & 8 & 150 & 400 \\
\hline \multirow[t]{3}{*}{0.7 Cement } & $A$ & 0 & 1 & 3 & 17 & 600 & $>750$ \\
\hline & $\mathrm{B}$ & 0 & 1 & 3 & 17 & 600 & $>750$ \\
\hline & $c$ & 0 & 1 & 3 & 17 & 625 & $>750$ \\
\hline \multicolumn{8}{|c|}{ 60-Percent Moisture } \\
\hline \multirow[t]{3}{*}{0.1 Cement } & A & 2 & 2 & 5 & 12 & 30 & 30 \\
\hline & $B$ & 3 & 3 & 5 & 13 & 35 & 30 \\
\hline & $\mathrm{c}$ & 2 & 3 & 5 & 13 & 30 & 30 \\
\hline \multirow[t]{3}{*}{0.4 Cement } & A & 3 & 4 & 10 & 20 & 350 & $>750$ \\
\hline & $B$ & 4 & 4 & 9 & 20 & 400 & $>750$ \\
\hline & $\mathrm{C}$ & 4 & 4 & 10 & 19 & 450 & $>750$ \\
\hline \multirow[t]{3}{*}{0.7 Cement } & $\mathrm{A}$ & 2 & 5 & 8 & 30 & $>750$ & $>750$ \\
\hline & $\mathrm{B}$ & 2 & 5 & 9 & 30 & $>750$ & $>750$ \\
\hline & $c$ & 2 & 5 & 10 & 30 & $>750$ & $>750$ \\
\hline
\end{tabular}




\begin{tabular}{|c|c|c|c|c|c|c|c|}
\hline \multicolumn{8}{|c|}{$\begin{array}{l}\text { Table B2 } \\
\text { Cl Results of Lime/Fly Ash Binders }\end{array}$} \\
\hline \multirow[b]{2}{*}{ Binder Ratio } & \multirow[b]{2}{*}{ Replicate } & \multicolumn{6}{|c|}{ Cone Index, psi } \\
\hline & & $1 \mathrm{hr}$ & $2 \mathrm{hr}$ & $4 \mathrm{hr}$ & $8 \mathrm{hr}$ & $24 \mathrm{hr}$ & $48 \mathrm{hr}$ \\
\hline \multicolumn{8}{|c|}{ 68-Percent Moisture } \\
\hline \multirow{3}{*}{ 0.1/0.1 Lime/Fly Ash } & A & 0 & 0 & 0 & 5 & 5 & 5 \\
\hline & $\mathrm{B}$ & 0 & 0 & 0 & 5 & 5 & 5 \\
\hline & C & 0 & 0 & 0 & 5 & 5 & 5 \\
\hline \multirow[t]{3}{*}{ 0.2/0.2 Lime/Fly Ash } & A & 0 & 0 & 5 & 5 & 5 & 10 \\
\hline & $B$ & 0 & 0 & 5 & 5 & 5 & 10 \\
\hline & $\mathrm{C}$ & 0 & 0 & 5 & 5 & 5 & 10 \\
\hline \multirow[t]{3}{*}{ 0.3/0.3 Lime/Fly Ash } & A & 1 & 3 & 5 & 9 & 10 & 17 \\
\hline & $\mathrm{B}$ & 1 & 3 & 5 & 9 & 10 & 18 \\
\hline & $\mathrm{C}$ & 1 & 3 & 5 & 9 & 10 & 19 \\
\hline \multicolumn{8}{|c|}{ 60-Percent Moisture } \\
\hline \multirow[t]{3}{*}{ 0.1/0.1 Lime/Fly Ash } & A & 2 & 3 & 7 & 5 & 10 & 10 \\
\hline & $\mathrm{B}$ & 2 & 3 & 8 & 4 & 10 & 10 \\
\hline & $\mathrm{C}$ & 2 & 2 & 8 & 4 & 10 & 10 \\
\hline \multirow[t]{3}{*}{ 0.2/0.2 Lime/Fly Ash } & $A$ & 3 & 10 & 19 & 15 & 30 & 20 \\
\hline & B & 4 & 10 & 19 & 15 & 30 & 20 \\
\hline & $\mathrm{C}$ & 4 & 10 & 19 & 15 & 28 & 20 \\
\hline \multirow[t]{3}{*}{ 0.3/0.3 Lime/Fly Ash } & A & 35 & 38 & 40 & 60 & 90 & 50 \\
\hline & $\mathrm{B}$ & 40 & 40 & 40 & 60 & 80 & 60 \\
\hline & $c$ & 30 & 38 & 42 & 60 & 85 & 70 \\
\hline
\end{tabular}




\section{Appendix C Results of Detailed Evaluation}

\begin{tabular}{|c|c|c|c|c|c|}
\hline \multicolumn{6}{|c|}{$\begin{array}{l}\text { Table C1 } \\
\text { Results of Physical Tests for Detailed Evaluation }\end{array}$} \\
\hline Binder Ratio & Replicate & \begin{tabular}{|l|}
$\begin{array}{l}\text { Moisture Con- } \\
\text { tent, Percent }\end{array}$ \\
\end{tabular} & $\begin{array}{l}\text { Bulk Den- } \\
\text { sity, } \mathrm{lb} / \mathrm{tt}^{3}\end{array}$ & $\begin{array}{l}\text { Volume Increase } \\
\text { Percent }\end{array}$ & Slump, in. \\
\hline 0.2 Cement & A & 37.7 & 73.7 & & \\
\hline 0.2 Cement & $B$ & 35.3 & 74.1 & 54.7 & 2 \\
\hline 0.2 Cement & $\mathrm{C}$ & 37.5 & 72.5 & & \\
\hline 0.4 Cement & A & 30.5 & 85.2 & & \\
\hline 0.4 Cement & $B$ & 31.0 & 86.5 & 55.0 & 0.5 \\
\hline 0.4 Cement & $\mathrm{C}$ & 34.5 & 84.9 & & \\
\hline 0.6 Cement & A & 22.6 & 96.8 & & \\
\hline 0.6 Cement & $B$ & 22.2 & 93.4 & 57.0 & 0.5 \\
\hline 0.6 Cement & $c$ & 21.5 & 99.3 & & \\
\hline 0.8 Cement & A & 21.3 & 101.7 & & \\
\hline 0.8 Cement & $B$ & 21.8 & 102.6 & 65.0 & 0.0 \\
\hline 0.8 Cement & C & 21.5 & 105.9 & & \\
\hline 0.3/0.4 Lime/Fly Ash & A & 24.6 & 78.5 & & \\
\hline 0.3/0.4 Lime/Fly Ash & $B$ & 24.1 & 76.6 & 107 & 0.0 \\
\hline 0.3/0.4 Lime/Fly Ash & $c$ & 24.2 & 77.7 & & \\
\hline 0.3/0.6 Lime/Fly Ash & A & 19.6 & 85.8 & & \\
\hline 0.3/0.6 Lime/Fly Ash & $B$ & 21.2 & 85.6 & 112 & 0.0 \\
\hline 0.3/0.6 Lime/Fly Ash & $c$ & 19.6 & 83.2 & & \\
\hline 0.4/0.4 Lime/Fly Ash & A & 22.7 & 85.3 & & \\
\hline 0.4/0.4 Lime/Fly Ash & B & 22.2 & 87.2 & 99.9 & 0.0 \\
\hline 0.4/0.4 Lime/Fly Ash & $c$ & 23.9 & 83.2 & & \\
\hline 0.4/0.6 Lime/Fly Ash & A & 16.8 & 83.9 & & \\
\hline 0.4/0.6 Lime/Fly Ash & $B$ & 20.1 & 85.2 & 126 & 0.0 \\
\hline 0.4/0.6 Lime/Fly Ash & c & 20.4 & 81.7 & & \\
\hline
\end{tabular}




\begin{tabular}{|c|c|c|c|c|c|c|c|}
\hline \multirow[b]{2}{*}{ Binder Ratio } & \multirow[b]{2}{*}{ Replicate } & \multicolumn{6}{|c|}{ Cone Index, psi } \\
\hline & & $1 \mathrm{hr}$ & $2 \mathrm{hr}$ & $4 \mathrm{hr}$ & $8 \mathrm{hr}$ & $24 \mathrm{hr}$ & $48 \mathrm{hr}$ \\
\hline 0.2 Cement & A & 0 & 0 & 4 & 20 & 110 & 386 \\
\hline 0.2 Cement & B & 0 & 0 & 6 & 20 & 113 & 373 \\
\hline 0.2 Cement & $\mathrm{c}$ & 0 & 0 & 6 & 20 & 117 & 375 \\
\hline 0.4 Cement & A & 0 & 1 & 18 & 20 & 600 & $>750$ \\
\hline 0.4 Cement & B & 0 & 2 & 19 & 20 & 650 & $>750$ \\
\hline 0.4 Cement & $\mathrm{c}$ & 0 & 2 & 19 & 20 & 700 & $>750$ \\
\hline 0.6 Cement & A & 0 & 14 & 15 & 24 & $>750$ & $>750$ \\
\hline 0.6 Cement & B & 0 & 15 & 15 & 25 & $>750$ & $>750$ \\
\hline 0.6 Cement & $\mathrm{C}$ & 0 & 14 & 15 & 25 & $>750$ & $>750$ \\
\hline 0.8 Cement & A & 16 & 17 & 21 & 46 & $>750$ & $>750$ \\
\hline 0.8 Cement & $\mathrm{B}$ & 16 & 21 & 22 & 46 & $>750$ & $>750$ \\
\hline 0.8 Cement & $\mathrm{c}$ & 15 & 22 & 22 & 48 & $>750$ & $>750$ \\
\hline 0.3/0.4 Lime/Fly Ash & A & 27 & 30 & 30 & 20 & 100 & $>750$ \\
\hline 0.3/0.4 Lime/Fly Ash & B & 20 & 31 & 31 & 20 & 100 & $>750$ \\
\hline 0.3/0.4 Lime/Fly Ash & $\mathrm{c}$ & 25 & 27 & 36 & 20 & 100 & $>750$ \\
\hline 0.3/0.6 Lime/Fly Ash & A & 39 & 40 & 39 & 55 & 63 & 53 \\
\hline 0.3/0.6 Lime/Fly Ash & $\mathrm{B}$ & 35 & 40 & 40 & 62 & 68 & 78 \\
\hline 0.3/0.6 Lime/Fly Ash & $c$ & 38 & 39 & 40 & 68 & 71 & 87 \\
\hline 0.4/0.4 Lime/Fly Ash & A & 39 & 40 & 40 & 42 & 65 & 93 \\
\hline 0.4/0.4 Lime/Fly Ash & B & 38 & 43 & 53 & 42 & 67 & 80 \\
\hline 0.4/0.4 Lime/Fly Ash & $\mathrm{c}$ & 41 & 41 & 50 & 50 & 65 & 83 \\
\hline 0.4/0.6 Lime/Fly Ash & A & 40 & 46 & 47 & 58 & 95 & 90 \\
\hline 0.4/0.6 Lime/Fly Ash & B & 35 & 43 & 47 & 58 & 77 & 92 \\
\hline 0.4/0.6 Lime/Fly Ash & C & 42 & 42 & 53 & 60 & 83 & 108 \\
\hline
\end{tabular}




\begin{tabular}{|c|c|c|c|c|c|}
\hline \multicolumn{6}{|c|}{$\begin{array}{l}\text { Table C3 } \\
\text { UCS Results for the Detailed Evaluation }\end{array}$} \\
\hline \multirow[b]{2}{*}{ Binder Ratio } & \multirow[b]{2}{*}{ Replicate } & \multicolumn{4}{|c|}{ UCS Results, psi } \\
\hline & & 7 Day & 14 Day & 21 Day & 28 Day \\
\hline 0.2 Cement & $A$ & 121 & 192 & 228 & 243 \\
\hline 0.2 Cement & $\mathrm{B}$ & 96 & 192 & 225 & 255 \\
\hline 0.2 Cement & $\mathrm{C}$ & 128 & 203 & 194 & 248 \\
\hline 0.4 Cement & $A$ & 440 & 669 & 572 & 725 \\
\hline 0.4 Cement & $B$ & 460 & 574 & 609 & 715 \\
\hline 0.4 Cement & $\mathrm{c}$ & 473 & 595 & 626 & 758 \\
\hline 0.6 Cement' $^{\prime}$ & A & 823 & 1,506 & 336 & 872 \\
\hline 0.6 Cement $^{1}$ & $\mathrm{~B}$ & 1,032 & 1,026 & 814 & 858 \\
\hline 0.6 Cement $^{1}$ & $\mathrm{C}$ & 1,307 & 862 & 784 & 1,237 \\
\hline 0.8 Cement $^{t}$ & A & 1,077 & 859 & 985 & 1,216 \\
\hline 0.8 Cement $^{1}$ & B & 693 & 1,353 & 709 & 793 \\
\hline 0.8 Cement $^{1}$ & $\mathrm{C}$ & 567 & 853 & 531 & 721 \\
\hline 0.3/0.4 Lime/Fly Ash & A & 51 & 149 & 135 & 171 \\
\hline 0.3/0.4 Lime/Fly Ash & $\mathrm{B}$ & 43 & 141 & 172 & 214 \\
\hline 0.3/0.4 Lime/Fly Ash & $\mathrm{c}$ & 37 & 148 & 159 & 179 \\
\hline 0.3/0.6 Lime/Fly Ash & A & 57 & 166 & 227 & 207 \\
\hline 0.3/0.6 Lime/Fly Ash & $\mathrm{B}$ & 66 & 154 & 169 & 249 \\
\hline 0.3/0.6 Lime/Fly Ash & $\mathrm{C}$ & 43 & 173 & 242 & 215 \\
\hline 0.4/0.4 Lime/Fly Ash & A & 84 & 169 & 197 & 213 \\
\hline 0.4/0.4 Lime/Fly Ash & $\mathrm{B}$ & 90 & 160 & 177 & 321 \\
\hline 0.4/0.4 Lime/Fly Ash & $\mathrm{C}$ & 112 & 226 & 227 & 204 \\
\hline 0.4/0.6 Lime/Fly Ash & A & 54 & 131 & 229 & 270 \\
\hline 0.4/0.6 Lime/Fly Ash & $\mathrm{B}$ & 64 & 177 & 177 & 273 \\
\hline 0.4/0.6 Lime/Fly Ash & C & 56 & 151 & 183 & 218 \\
\hline
\end{tabular}




\begin{tabular}{|c|c|c|c|c|c|c|c|c|}
\hline \multicolumn{9}{|c|}{$\begin{array}{l}\text { Table C4 } \\
\text { Results of TCLP Screening for Treated Sediment }\end{array}$} \\
\hline Sample ID & Replicate & Cd, mg/e & $\mathrm{Cr}, \mathrm{mg} / \mathbf{\ell}$ & $\mathrm{Cu}, \mathrm{mg} / \mathrm{\ell}$ & $\mathrm{Pb}, \mathrm{mg} / \mathrm{e}$ & $\mathrm{Hg}, \mathrm{mg} / \mathrm{l}$ & $\mathrm{Ni}, \mathrm{mg} / \mathrm{l}$ & $\mathrm{Zn}, \mathrm{mg} / \mathrm{\ell}$ \\
\hline \multirow[t]{3}{*}{ Untreated } & A & $<0.010$ & 0.094 & 0.012 & 0.092 & $<0.0002$ & 0.059 & 0.197 \\
\hline & $B$ & $<0.010$ & 0.084 & $<0.007$ & 0.060 & $<0.0002$ & 0.049 & 0.214 \\
\hline & $c$ & $<0.010$ & 0.097 & 0.015 & 0.075 & $<0.0002$ & 0.062 & 0.253 \\
\hline \multirow[t]{3}{*}{0.2 Cement } & A & $<0.005$ & $<0.010$ & 2.03 & $<0.050$ & 0.00152 & 0.308 & 0.180 \\
\hline & $B$ & $<0.005$ & $<0.010$ & 2.04 & 0.058 & 0.00052 & 0.293 & 0.156 \\
\hline & $c$ & $<0.005$ & $<0.010$ & 2.11 & 0.052 & 0.00036 & 0.314 & 0.120 \\
\hline \multirow[t]{3}{*}{0.4 Cement } & A & $<0.005$ & $<0.010$ & 1.21 & $<0.050$ & 0.00046 & 0.350 & 0.131 \\
\hline & $\mathrm{B}$ & $<0.005$ & 0.014 & 1.37 & $<0.050$ & 0.00037 & 0.388 & 0.186 \\
\hline & c & $<0.005$ & $<0.010$ & 1.15 & $<0.050$ & 0.00055 & 0.329 & 0.159 \\
\hline \multirow[t]{3}{*}{0.6 Cement } & A & $<0.005$ & $<0.010$ & 0.401 & $<0.050$ & 0.00028 & 0.165 & 0.156 \\
\hline & $B$ & $<0.005$ & $<0.010$ & 0.356 & $<0.050$ & 0.00021 & 0.163 & 0.155 \\
\hline & $c$ & $<0.005$ & $<0.010$ & 0.273 & $<0.050$ & 0.00037 & 0.150 & 0.110 \\
\hline \multirow[t]{3}{*}{0.8 Cement } & A & $<0.005$ & $<0.010$ & 0.437 & $<0.050$ & 0.00056 & 0.169 & 0.120 \\
\hline & B & $<0.005$ & $<0.010$ & 0.497 & $<0.050$ & 0.00030 & 0.190 & 0.120 \\
\hline & $c$ & $<0.005$ & $<0.010$ & 0.346 & $<0.05 a$ & 0.00071 & 0.164 & 0.149 \\
\hline \multirow[t]{3}{*}{ 0.3/0.4 Lime/Fly Ash } & A & $<0.010$ & $<0.009$ & 0.843 & 0.105 & 0.00036 & 0.222 & 0.276 \\
\hline & B & $<0.010$ & $<0.009$ & 0.883 & 0.088 & $<0.0002$ & 0.253 & 0.161 \\
\hline & c & $<0.010$ & $<0.009$ & 0.793 & $<0.050$ & $<0.0002$ & 0.231 & 0.162 \\
\hline \multirow[t]{3}{*}{ 0.3/0.6 Lime/Fly Ash } & A & $<0.010$ & $<0.009$ & 0.574 & $<0.050$ & $<0.0002$ & 0.194 & 0.131 \\
\hline & $\mathrm{B}$ & $<0.010$ & $<0.009$ & 0.626 & $<0.050$ & $<0.0002$ & 0.205 & 0.184 \\
\hline & $\mathrm{c}$ & $<0.010$ & 0.015 & 0.536 & $<0.050$ & $<0.0002$ & 0.170 & 0.165 \\
\hline \multirow[t]{3}{*}{ 0.4/0.4 Lime/Fly Ash } & A & $<0.010$ & $<0.009$ & 0.741 & 0.091 & 0.00025 & 0.186 & 0.216 \\
\hline & B & $<0.010$ & $<0.009$ & 0.738 & 0.092 & $<0.0002$ & 0.202 & 0.197 \\
\hline & c & $<0.010$ & $<0.009$ & 0.743 & 0.088 & $<0.0002$ & 0.203 & 0.206 \\
\hline \multirow[t]{3}{*}{ 0.4/0.6 Lime/Fly Ash } & A & $<0.010$ & $<0.009$ & 0.652 & $<0.050$ & 0.00022 & 0.169 & 0.206 \\
\hline & $B$ & $<0.010$ & $<0.009$ & 0.671 & $<0.050$ & $<0.0002$ & 0.188 & 0.139 \\
\hline & $c$ & $<0.010$ & $<0.009$ & 0.644 & $<0.050$ & $<0.0002$ & 0.185 & 0.158 \\
\hline
\end{tabular}




\begin{tabular}{|c|c|c|c|c|c|}
\hline \multicolumn{6}{|c|}{$\begin{array}{l}\text { Table C5 } \\
\text { Results for Metals for the TCLP Performed by Triangle Laborato- } \\
\text { ries for the Treated NY/NJ Harbor Sediment }\end{array}$} \\
\hline Analyte, $\mathrm{mg} / \mathrm{\ell}$ & Untreated & 0.4 Cement & 0.4 Cement & $\begin{array}{l}0.3 / 0.6 \\
\text { Lime/Fly Ash }\end{array}$ & $\begin{array}{l}0.3 / 0.6 \\
\text { Lime/Fiy Ash }\end{array}$ \\
\hline Arsenic & 0.1 & $<0.1$ & $<0.1$ & $<0.1$ & $<0.1$ \\
\hline Barium & 0.5 & $<0.5$ & $<0.5$ & 0.7 & 0.9 \\
\hline Cadmium & 0.001 & $<0.01$ & $<0.01$ & $<0.01$ & $<0.01$ \\
\hline Chromium & 0.02833 & $<0.01$ & $<0.01$ & $<0.01$ & $<0.01$ \\
\hline Lead & 0.05 & $<0.05$ & $<0.05$ & $<0.05$ & $<0.05$ \\
\hline Mercury & 0.001 & $<0.001$ & $<0.001$ & $<0.001$ & $<0.001$ \\
\hline Selenium & 0.1 & $<0.1$ & $<0.1$ & $<0.1$ & $<0.1$ \\
\hline Silver & 0.01 & $<0.01$ & $<0.01$ & $<0.01$ & $<0.01$ \\
\hline
\end{tabular}

\begin{tabular}{|c|c|c|c|c|}
\hline \multicolumn{5}{|c|}{$\begin{array}{l}\text { Table } \mathrm{C6} \\
\text { Results for Organochlorine Pesticides for the TCLP Performed } \\
\text { by Triangle Laboratories for the Treated NY/NJ Harbor Sediment }\end{array}$} \\
\hline Analyte, $\mathrm{mg} / \mathrm{\ell}$ & 0.4 Cement & 0.4 Cement & $\begin{array}{l}0.3 / 0.6 \\
\text { Lime/Fly Ash }\end{array}$ & $\begin{array}{l}0.3 / 0.6 \\
\text { Lime/Fly Ash }\end{array}$ \\
\hline Chlordane & $<0.005$ & $<0.005$ & $<0.005$ & $<0.005$ \\
\hline Endrin & $<0.0005$ & $<0.0005$ & $<0.0005$ & $<0.0005$ \\
\hline Heptachlor & $<0.0005$ & $<0.0005$ & $<0.0005$ & $<0.0005$ \\
\hline Heptachlor Epoxide & $<0.0005$ & $<0.0005$ & $<0.0005$ & $<0.0005$ \\
\hline Lindane & $<0.0005$ & $<0.0005$ & $<0.0005$ & $<0.0005$ \\
\hline Methoxychlor & $<0.001$ & $<0.001$ & $<0.001$ & $<0.001$ \\
\hline Toxaphene & $<0.01$ & $<0.01$ & $<0.01$ & $<0.01$ \\
\hline
\end{tabular}

\begin{tabular}{|c|c|c|c|c|}
\hline Analyte, $\mathrm{mg} / \mathrm{\ell}$ & 0.4 Cement & 0.4 Cement & $\begin{array}{l}0.3 / 0.6 \\
\text { Lime/Fiy Ash }\end{array}$ & $\begin{array}{l}0.3 / 0.6 \\
\text { Lime/Fly Ash }\end{array}$ \\
\hline 2,4-D & $<0.1$ & $<0.1$ & $<0.1$ & $<0.1$ \\
\hline $2,4,5-T P$ & $<0.01$ & $<0.01$ & $<0.01$ & $<0.01$ \\
\hline
\end{tabular}




\begin{tabular}{|c|c|c|c|c|}
\hline \multicolumn{5}{|c|}{$\begin{array}{l}\text { Table C8 } \\
\text { Results for Volatile Organic Compounds for the TCLP Per- } \\
\text { formed by Triangle Laboratories for the Treated NY/NJ Harbor } \\
\text { Sediment }\end{array}$} \\
\hline Analyte, $\mathrm{mg} / \mathrm{\ell}$ & 0.4 Cement & 0.4 Cement & $\begin{array}{l}0.3 / 0.6 \\
\text { Lime/Fly Ash } \\
\end{array}$ & $\begin{array}{l}0.3 / 0.6 \\
\text { Lime/Fly Ash }\end{array}$ \\
\hline Benzene & $<0.2$ & $<0.2$ & $<0.2$ & $<0.2$ \\
\hline Carbon Tetrachloride & $<0.2$ & $<0.2$ & $<0.2$ & $<0.2$ \\
\hline Chlorobenzene & $<0.2$ & $<0.2$ & $<0.2$ & $<0.2$ \\
\hline 1,4-Dichlorobenzene & $<0.2$ & $<0.2$ & $<0.2$ & $<0.2$ \\
\hline 1,2-Dichloroethane & $<0.2$ & $<0.2$ & $<0.2$ & $<0.2$ \\
\hline 1,1-Dichloroethene & $<0.2$ & $<0.2$ & $<0.2$ & $<0.2$ \\
\hline Methyl Ethyl Ketone & $<0.2$ & $<0.2$ & $<0.2$ & $<0.2$ \\
\hline Tetrachloroethene & $<0.2$ & $<0.2$ & $<0.2$ & $<0.2$ \\
\hline Trichloroethene & $<0.2$ & $<0.2$ & $<0.2$ & $<0.2$ \\
\hline Vinyl Chloride & $<0.1$ & $<0.1$ & $<0.1$ & $<0.1$ \\
\hline
\end{tabular}




\begin{tabular}{|c|c|c|c|c|}
\hline \multicolumn{5}{|c|}{$\begin{array}{l}\text { Table C9 } \\
\text { Results for Semivolatile Organic Compounds for the TCLP } \\
\text { Performed by Triangle Laboratories for the Treated NY/NJ } \\
\text { Harbor Sediment }\end{array}$} \\
\hline Analyte, $\mathrm{mg} / \mathrm{\ell}$ & 0.4 Cement & 0.4 Cement & $\begin{array}{l}0.3 / 0.6 \\
\text { Lime/Fly Ash }\end{array}$ & $\begin{array}{l}0.3 / 0.6 \\
\text { Lime/Fly Ash }\end{array}$ \\
\hline Pyridine & $<0.25$ & $<0.25$ & $<0.25$ & $<0.25$ \\
\hline o-Cresol & $<0.1$ & $<0.1$ & $<0.1$ & $<0.1$ \\
\hline Hexachloroethane & $<0.1$ & $<0.1$ & $<0.1$ & $<0.1$ \\
\hline $\mathrm{m}, \mathrm{p}$-Cresol & $<0.1$ & $<0.1$ & $<0.1$ & $<0.1$ \\
\hline Nitrobenzene & $<0.1$ & $<0.1$ & $<0.1$ & $<0.1$ \\
\hline Hexachlorobutadiene & $<0.1$ & $<0.1$ & $<0.1$ & $<0.1$ \\
\hline 2,4,6-Trichlorophenol & $<0.1$ & $<0.1$ & $<0.1$ & $<0.1$ \\
\hline 2,4,5-Trichlorophenol & $<0.10$ & $<0.1$ & $<0.1$ & $<0.1$ \\
\hline 2,4-Dinitrotoluene & $<0.10$ & $<0.10$ & $<0.10$ & $<0.10$ \\
\hline Hexachlorobenzene & $<0.25$ & $<0.10$ & $<0.10$ & $<0.10$ \\
\hline Pentachlorophenol & $<0.1$ & $<0.25$ & $<0.25$ & $<0.25$ \\
\hline Total Cresols & $<0.1$ & $<0.1$ & $<0.1$ & $<0.1$ \\
\hline Napthalene & $<0.1$ & $<0.1$ & $<0.1$ & $<0.1$ \\
\hline 2-Methyl Napthalene & $<0.1$ & $<0.1$ & $<0.1$ & $<0.1$ \\
\hline Acenaphthylene & $<0.1$ & $<0.1$ & $<0.1$ & $<0.1$ \\
\hline Acenaphthene & $<0.1$ & $<0.1$ & $<0.1$ & $<0.1$ \\
\hline Dibenzofuran & $<0.1$ & $<0.1$ & $<0.1$ & $<0.1$ \\
\hline Fluorene & $<0.1$ & $<0.1$ & $<0.1$ & $<0.1$ \\
\hline Phenanthrene & $<0.1$ & $<0.1$ & $<0.1$ & $<0.1$ \\
\hline Anthacene & $<0.1$ & $<0.1$ & $<0.1$ & $<0.1$ \\
\hline Fluoranthene & $<0.1$ & $<0.1$ & $<0.1$ & $<0.1$ \\
\hline Pyrene & $<0.1$ & $<0.1$ & $<0.1$ & $<0.1$ \\
\hline Benz(a)anthracene & $<0.1$ & $<0.1$ & $<0.1$ & $<0.1$ \\
\hline Chrysene & $<0.1$ & $<0.1$ & $<0.1$ & $<0.1$ \\
\hline Benzo(b)Fluoranthene & $<0.1$ & $<0.1$ & $<0.1$ & $<0.1$ \\
\hline Benzo(k)Fluoranthene & $<0.1$ & $<0.1$ & $<0.1$ & $<0.1$ \\
\hline Benzo(a)pyrene & $<0.1$ & $<0.1$ & $<0.1$ & $<0.1$ \\
\hline Ideno(1,2,3-cd)pyrene & $<0.1$ & $<0.1$ & $<0.1$ & $<0.1$ \\
\hline Dibenz(a,h)anthracene & $<0.1$ & $<0.1$ & $<0.1$ & $<0.1$ \\
\hline Benzo(g,h,i)perylene & $<0.1$ & $<0.1$ & $<0.1$ & $<0.1$ \\
\hline
\end{tabular}




\begin{tabular}{|c|c|c|c|c|c|}
\hline \multicolumn{6}{|c|}{$\begin{array}{l}\text { Table C10 } \\
\text { Results for PCDD/PCDF for the TCLP Performed by Triangle Lab- } \\
\text { oratories for the Treated NY/NJ Harbor Sediment }\end{array}$} \\
\hline Analyte, ppq & \begin{tabular}{|l|} 
Untreated \\
Sediment
\end{tabular} & 0.4 Cement & 0.4 Cement & $\begin{array}{l}0.3 / 0.6 \\
\text { Lime/Fly Ash }\end{array}$ & $\begin{array}{l}0.3 / 0.6 \\
\text { Lime/Fly Ash }\end{array}$ \\
\hline 2378 TCDD & 3.17 & $<2.7$ & $<5.7$ & $<5.8$ & $<8$ \\
\hline 12378 PeCDD & 7.17 & $<7.9$ & $<15.8$ & $<13.3$ & $<18.3$ \\
\hline $123478 \mathrm{HxCDD}$ & 7.0 & $<6.7$ & $<12.7$ & $<10$ & $<11.8$ \\
\hline $123678 \mathrm{HxCDD}$ & 6.0 & $<6.0$ & $<11.4$ & $<9$ & $<10.9$ \\
\hline $123789 \mathrm{HxCDD}$ & 6.17 & $<6.2$ & $<1.6$ & $<9.2$ & $<11.3$ \\
\hline $1234678 \mathrm{HpCDD}$ & 6.87 & $<9.1$ & $<5.5$ & $<12.4$ & $<12.9$ \\
\hline 12346789 OCDD & 30.33 & $<19.7$ & $<37.3$ & $<14.1$ & $<25$ \\
\hline 2378 TCDF & 2.33 & $<8.3$ & $<4$ & $<4$ & $<5.3$ \\
\hline $12378 P_{\ominus C D F}$ & 4.17 & $<4.2$ & $<8.8$ & $<8.1$ & $<10.8$ \\
\hline 23478 PeCDF & 4.0 & $<3.9$ & $<8.2$ & $<7.5$ & $<8.8$ \\
\hline $123478 \mathrm{HxCDF}$ & 5.33 & $<3.6$ & $<7.3$ & $<5.6$ & $<7.1$ \\
\hline $123678 \mathrm{HXCDF}$ & 3.17 & $<2.8$ & $<5.7$ & $<4.3$ & $<5.5$ \\
\hline $234678 \mathrm{HxCDF}$ & 4.87 & $<4.7$ & $<3.5$ & $<5.7$ & $<7$ \\
\hline $123789 \mathrm{HxCDF}$ & 4.67 & $<4.2$ & $<8.6$ & $<6.5$ & $<7.5$ \\
\hline $1234678 \mathrm{HpCDF}$ & 9.25 & $<3.7$ & 8.0 & $<2.7$ & $<5.6$ \\
\hline $1234789 \mathrm{HpCDF}$ & 6.5 & $<5.9$ & $<11.2$ & $<7.9$ & $<9.3$ \\
\hline 12346789 OCDF & 8.83 & $<13.9$ & $<27.5$ & $<17.6$ & $<17$ \\
\hline TOTAL TCDD & 3.17 & $<2.7$ & $<5.7$ & $<5.8$ & $<8$ \\
\hline TOTAL PeCDD & 7.17 & $<7.9$ & $<15.8$ & $<13.3$ & $<18.3$ \\
\hline TOTAL HXCDD & 6.17 & $<6.3$ & $<11.9$ & $<9.4$ & $<11.3$ \\
\hline TOTAL HpCDD & 11.67 & $<9.1$ & $<5.5$ & $<12.4$ & $<12.9$ \\
\hline TOTAL TCDF & 2.33 & $<8.3$ & $<4.0$ & $<4.0$ & $<5.3$ \\
\hline TOTAL PECDF & 4.0 & $<4.1$ & $<8.5$ & $<7.7$ & $<9.7$ \\
\hline TOTAL HXCDF & 11.0 & $<4.7$ & $<8.5$ & $<5.4$ & $<6.7$ \\
\hline TOTAL HpCDF & 9.25 & $<4.5$ & 8 & $<2.7$ & $<7.0$ \\
\hline
\end{tabular}




\begin{tabular}{|c|c|c|c|c|c|}
\hline \multicolumn{6}{|c|}{$\begin{array}{l}\text { Table } C 11 \\
\text { Results for Polychlorinated Biphenyls for the TCLP Performed by Triangle Laborato- } \\
\text { ries for the Treated NY/NJ Harbor Sediment }\end{array}$} \\
\hline Analyte, ppt & $\begin{array}{l}\text { Untreated } \\
\text { Sediment } \\
\end{array}$ & 0.4 Cement & 0.4 Cement & $\begin{array}{l}\mathbf{0 . 3 / 0 . 6} \\
\text { Lime/Fly Ash } \\
\end{array}$ & $\begin{array}{l}0.3 / 0.6 \\
\text { Lime/Fly Ash }\end{array}$ \\
\hline 2-MonoCB & 28.03 & 33.5 & 33.9 & 21.8 & 23.3 \\
\hline 4,4'-DiCB & 3.42 & 3.2 & 3.2 & 1.4 & 1.6 \\
\hline 2,4,4'TriCB & 5.83 & 3.2 & 3.3 & 3.6 & 3.9 \\
\hline $2,2^{\prime}, 5,5^{\prime}$-TetraCB & 3.07 & 1.4 & 1.3 & 3.0 & 2.4 \\
\hline 3,3',4,4'-TetraCB & 0.24 & ND & 0.07 & 0.08 & ND \\
\hline 2,3',4,4,5-PentaCB & 0.12 & 0.06 & ND & ND & ND \\
\hline $2,3,3^{\prime}, 4,4^{\prime}$-PentaCB & 1.06 & ND & 0.07 & 0.27 & 0.19 \\
\hline 3,3,4,4,5-PentaCB & 0.04 & ND & ND & ND & ND \\
\hline $2,3,3^{\prime}, 4,4^{\prime}$-НехасВ & 0.31 & ND & ND & 0.06 & 0.04 \\
\hline $3,3^{\prime}, 4,4^{\prime}, 5,5^{\prime}$-HexaCB & 0.06 & ND & ND & ND & ND \\
\hline $2,2^{\prime}, 3,4,4^{\prime}, 5,5^{\prime}$-HeptaCB & 1.94 & ND & 0.09 & 0.40 & 0.22 \\
\hline $2,2^{\prime}, 3,3^{\prime}, 4,4^{\prime}, 5,5^{\prime}$-OctaCB & 0.39 & ND & ND & 0.08 & 0.06 \\
\hline $2,2^{\prime}, 3,3^{\prime}, 4,4^{\prime}, 5,5^{\prime}, 6$-NonaCB & 0.19 & ND & ND & ND & ND \\
\hline DecaCB & 0.14 & ND & ND & ND & ND \\
\hline Total MonoCB & 34.97 & 45.1 & 45.4 & 25.7 & 27.4 \\
\hline Total DiCB & 35.23 & 35.8 & 35.6 & 24.2 & 28.0 \\
\hline Total TricB & 36.82 & 27.5 & 26.3 & 28.0 & 31.0 \\
\hline Total TetraCB & 23.52 & 7.4 & 6.4 & 13.0 & 10.9 \\
\hline Total PentaCB & 15.62 & 1.0 & 0.90 & 4.0 & 3.0 \\
\hline Total HexaCB & 1.23 & 0.41 & 0.29 & 2.7 & 1.5 \\
\hline Total HeptaCB & 6.02 & ND & 0.09 & 0.53 & 0.37 \\
\hline Total OctaCB & 1.5 & ND & ND & 0.10 & 0.04 \\
\hline Total NonaCB & 0.22 & ND & ND & ND & ND \\
\hline
\end{tabular}




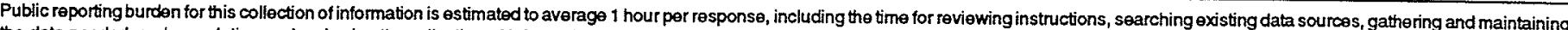

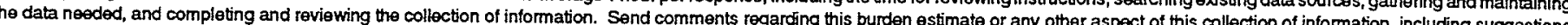

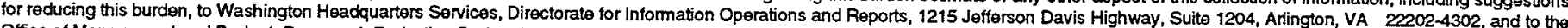
Office of Management and Budget, Paperwork Reduction Project (0704-0188), Washington, DC 20503.

\begin{tabular}{|l|l|l|l}
\hline 1. AGENCY USE ONLY (Leave blank) & $\begin{array}{l}\text { 2. REPORT DATE } \\
\text { June1997 }\end{array}$ & $\begin{array}{l}\text { 3. REPORT TYPE AND DATES COVERED } \\
\text { Final report }\end{array}$ \\
\hline
\end{tabular}

4. TITLE AND SUBTITLE

An Evaluation of Solidification/Stabilization for Treatment of NewYork/

5. FUNDING NUMBERS

New Jersey Harbor Sediments

6. AUTHOR(S)

Michael G. Channell, Daniel E. Averett

7. PERforming ORganization NAME(S) AND ADDRESS(ES)

U.S. Army Engineer Waterways Experiment Station

3909 Halls Ferry Road

Vicksburg, MS 39180-6199

8. PERFORMING ORGANIZATION REPORT NUMBER

Technical Report EL-97-10

10. SPONSORINGMONITORING AGENCY REPORT NUMBER

U.S. Army Engineer District, New York

Jacob K. Javits Federal Building

New York, NY 10278-0090

11. SUPPLEMENTARY NOTES

Available from National Technical Information Service, 5285 Port Royal Road, Springfield, VA 22161.

12a. DISTRIBUTION/AVAILABILITY STATEMENT

Approved for public release; distribution is unlimited.

12b. DISTRIBUTION CODE

13. ABSTRACT (Maximum 200 words)

Sediments from the New York/New Jersey Harbor must be routinely dredged to maintain navigable water depths for shipping channels and berthing areas for commerce and safe navigation. Ocean disposal has historically been used as the primary alternative for disposal of dredged materials. However, the sediments that accumulate in the Harbor may contain contaminants at concentrations high enough to prohibit direct ocean disposal or beneficial use.

This study evaluates solidification/stabilization (S/S) as an alternative to ocean disposal for the New York/New Jersey Harbor sediments. Generic binder formulations were evaluated to determine if S/S could treat the harbor sediments and the contaminants that are found in the sediments. The solidified sediments were subjected to various physical and chemical leach tests to determine the effectiveness of $S / S$ for the sediments and to determine if the solidified sediment could have beneficial use.

14. SUBJECT TERMS Dredged material Sediments
Solidification

Stabilization
15. NUMBER OF PAGES

62

16. PRICE CODE

\begin{tabular}{|l|l|}
\hline 17. SECURITY CLASSIFICATION & $\begin{array}{l}\text { 18. } \\
\text { OF REPORT }\end{array}$ \\
UNCLASSIFIED & $\begin{array}{l}\text { OF THIS PAGE } \\
\text { UNCLASIFICATION }\end{array}$ \\
\hline
\end{tabular}

NSN 7540-01-280-5500
Standard Form 298 (Rev. 2-89) Prescribed by ANSI Std. Z39-18 298-102 


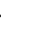

